- Conservation

Division of Buildings

and

Community Systems

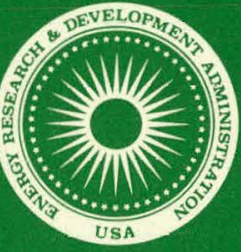

Robert A. Hoskins

Eric Hirst 


\section{DISCLAIMER}

This report was prepared as an account of work sponsored by an agency of the United States Government. Neither the United States Government nor any agency Thereof, nor any of their employees, makes any warranty, express or implied, or assumes any legal liability or responsibility for the accuracy, completeness, or usefulness of any information, apparatus, product, or process disclosed, or represents that its use would not infringe privately owned rights. Reference herein to any specific commercial product, process, or service by trade name, trademark, manufacturer, or otherwise does not necessarily constitute or imply its endorsement, recommendation, or favoring by the United States Government or any agency thereof. The views and opinions of authors expressed herein do not necessarily state or reflect those of the United States Government or any agency thereof. 


\section{DISCLAIMER}

Portions of this document may be illegible in electronic image products. Images are produced from the best available original document. 
Printed in the United States of America. Available from

National Technical Information Service

U.S. Department of Commerce

5285 Port Royal Road, Springfield, Virginia 22161

Price: Printed Copy $\$ 4,50 ;$ Microfiche $\$ 3.00$

This report was prepared as an account of work sponsored by the United States Government. Neither the United States nor the Energy Research and Development Administration/United States Nuclear Regulatory Commission, nor any of their employees, nor any of their contractors, subcontractors, or their employees, makes any warranty, express or implied, or assumes any legal liability or responsibility for the accuracy, completeness or usefulness of any information, apparatus, product or process disclosed, or represents that its use would not infringe privately owned rights. 
Contract No. W-7405-eng-26

ENERGY DIVISION

ENERGY AND COST ANALYSIS OF RESIDENTIAL WATER HEATERS

Robert A. Hoskins

Eric Hirst

This report was prepared as an account of work sponsored by the United the United States Energ Resench and Developmenl Administatin, nor any theis employees, not any of thes, makes any

subcontriulurs, of thrir employ assumes any leza

warranty, express or imples, accuracy, completeness

linbility of responsiby information, apparatus, product or

or usefuiness of any in represents that its use would not

process disclosed, or represents.

Date Published: June 1977

Research sponsored by the Federal Energy Administration and the

Energy Research and Development Administration

OAK RIDGE NATIONAL LABORATORY

Dak Ridge, Tennessee $\mathbf{3 7 8 3 0}$

operated by

UNION CARBIDE CORPORATION

for the

ENERGY RESEARCH AND DEVELOPMENT ADMINISTRATION

ep

DISTRIBUTION OF. THIS AOCUMENT IS UNLIMITED 
THIS PAGE

\section{WAS INTENTIONALLY \\ LEFT BLANK}




\title{
ENERGY AND COST ANALYSIS OF RESIDENTIAL WATER HEATERS
}

Robert A. Hoskins

Eric Hirst

\begin{abstract}
A detailed computer model is developed to calculate energy flows for residential electric and gas water heaters. Model equations are derived from applications of the first law of thermodynamics, analysis of manufacturers' literature, and related studies. The model is used to evaluate the energy (and associated initial cost) impacts of alternative designs to reduce water heater fuel use.

Model results show that the largest heat loss in an electric water heater is conduction through jacket walls ( $14 \%$ of energy input). An additional $5 \%$ is lost through the distribution pipe for a $7.6 \mathrm{~m}$ (25 ft) long pipe. The remaining $81 \%$ of energy input is used to heat water. In a gas water heater, conduction losses through jacket and distribution pipe are $12 \%$ and $3 \%$, respectively; and $33 \%$ is lost up the flue (due to main burner and pilot light operation). Only $52 \%$ of energy input to a gas water heater is used to heat water.

Several energy-saving design changes are examined using the energy mode1. Changes for both electric and gas water heaters are: increase jacket insulation thickness, reduce jacket insulation thermal conductivity, reduce thermostat setting, and add insulation to the distribution line. Application of all these changes to an electric water heater would reduce electricity use $17 \%$ and increase initial cost $27 \%$. Additional changes examined for gas water heaters are: reduce pilot rate, eliminate pilot and add electric ignitor and flue closure, and reduce excess air for combustion by increasing flue baffling. Implementing all these changes to a gas water heater (except addition of electric ignitor) would reduce gas use $27 \%$ and increase initial cost $26 \%$. These results show that there are large opportunities for reducing water heater energy use with only small initial cost increases.
\end{abstract}


THIS PAGE

\section{WAS INTENTIONALLY LEFT BLANK}


CONTENTS

$\underline{\text { Page }}$

ABSTRACT . . . . . . . . . . . . . . . . . . . . . . $i i i$

1. INTRODUCTION . . . . . . . . . . . . . . . . . . 1

2. MARKET TRENDS . . . . . . . . . . . . . . . 6

3. ENERGY MODEL . . . . . . . . . . . . . . . . . . . . . 9

4. VALIDATION OF ENERGY MODEL . . . . . . . . . . . . . . . . . 14

5. ENERGY-CONSERVING DESIGN OPTIONS . . . . . . . . . . . 16

6. NATIONAL EFFECTS OF REDUCING WATER HEATER ENERGY USE . . . $\quad 23$

7. CONCLUSIONS . . . . . . . . . . . . . . . . . . . 25

ACKNOWLEDGEMENTS . . . . . . . . . . . . . . . . . . 27

REFERENCES • . . . . . . . . . . . . . . . . . . . . . . . . 28

APPENDICES . . . . . . . . . . . . . . . . . . . . . 29

Appendix A: Nomenclature . . . . . . . . . . . . 29

Appendix B: Determination of flue loss . . . . . . . . . . 30

Appendix C: Sample calculations for a $0.19 \mathrm{~m}^{3}$ (50 gal)

electric and a $0.15 \mathrm{~m}^{3}$ (40 gal) gas

water heater . . . . . . . . . . . . 31

Appendix D: Energy-conserving options . . . . . . . . . . 37 


\section{INTRODUCTION}

This report describes a computer model that determines energy flows in residential electric and gas water heaters, and evaluates energy and cost (both operation and purchase) impacts of alternative energy-conserving design changes. Outputs from these analyses are used as inputs to a detailed engineering-economic model of residential energy use developed at ORNL. ${ }^{1}$ The energy use simulation model estimates distribution of new residential equipment each year (from 1970 through 2000) as functions of fuel prices, consumer demand functions, and technological characteristics of each type of equipment. The present study provides the relationships between operating energy requirement and initial cost for water heaters needed by the simulation model. The methodology used follows closely the work cited in ref. 2 .

Table 1 shows the 1970 distribution of residential energy use* by fuel and end use. ${ }^{1}$ Electric water heaters account for $6 \%$ of household fuel use and for $16 \%$ of residential electricity use. Gas water heaters account for $6 \%$ of household fuel use and for $17 \%$ of residential gas use, Thus, improvements in new water heaters can have significant long-term energy conservation effects.

Table 2 summarizes the energy impacts of design changes evaluated with our water heater model. Using more insulation with better thermal properties (item 2e) would reduce energy use of an electric water heater

\footnotetext{
* Table 1 shows electricity and gas in terms of their primary energy equivalents (29.7\% efficiency for electricity, $100 \%$ efficiency for gas). All subsequent fuel use figures are in terms of end use energy.
} 
Table 1. Household fuel use by fuel and end-use, 1970

\begin{tabular}{|c|c|c|c|c|c|c|}
\hline & Electricitya & Gas & Oil & other $b$ & \multicolumn{2}{|c|}{ Total } \\
\hline & \multicolumn{6}{|c|}{$\left(10^{18}\right.$ joules $)$} \\
\hline $\begin{array}{l}\text { Space heating } \\
\text { Water heating } \\
\text { Refrigeration } \\
\text { Freezing } \\
\text { Cooking } \\
\text { Air conditioning } \\
\text { Other }\end{array}$ & $\begin{array}{l}0.84 \\
0.88 \\
0.91 \\
0.31 \\
0.39 \\
0.70 \\
1.62\end{array}$ & $\begin{array}{l}3.92 \\
0.98 \\
0.32 \\
0.45\end{array}$ & $\begin{array}{l}3.39 \\
0.28\end{array}$ & $\begin{array}{l}0.82 \\
0.07\end{array}$ & $\begin{array}{l}8.97 \\
2.21 \\
0.91 \\
0.31 \\
0.74 \\
0.70 \\
2.07\end{array}$ & $\begin{array}{l}(56)^{c} \\
(14) \\
(6) \\
(2) \\
(5) \\
(4) \\
(13)\end{array}$ \\
\hline Total & $\begin{array}{l}5.65 \\
(35)^{c}\end{array}$ & $\begin{array}{l}5.67 \\
(36)\end{array}$ & $\begin{array}{l}3.67 \\
(23)\end{array}$ & $\begin{array}{l}0.92 \\
(6)\end{array}$ & 15.91 & \\
\hline
\end{tabular}

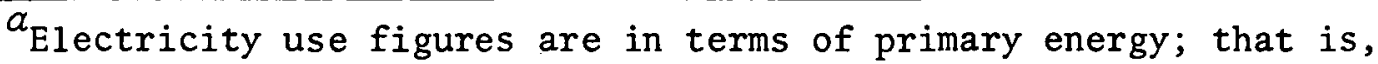
they include losses in generation, transmission, and distribution.

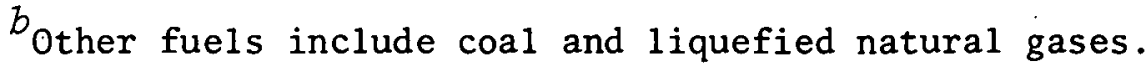

$c_{\text {Numbers }}$ in parentheses are percentages of the grand total, $15.9 \times 10^{18} \mathrm{~J}$.

$11 \%$ and increase purchase price $17 \%$. Making these changes to a gas water heater (item 2 e) would reduce gas use $13 \%$ and increase purchase price $16 \%$. Reduction of excess air for combustion and increase of flue baffling in gas water heaters (item 7) would reduce gas use $3 \%$ and increase purchase price less than $1 \%$. These and the other results presented in Table 2 and Figs. 1 and 2 show large opportunities for reducing energy use in new water heaters.

Section 2 discusses historical trends in water heater sales, ownership, type, lifetime, and energy use. These data are used to define typical electric and gas water heaters for the energy model to evaluate energy use with various design changes. 
Table 2. Water heater energy savings with various design changes

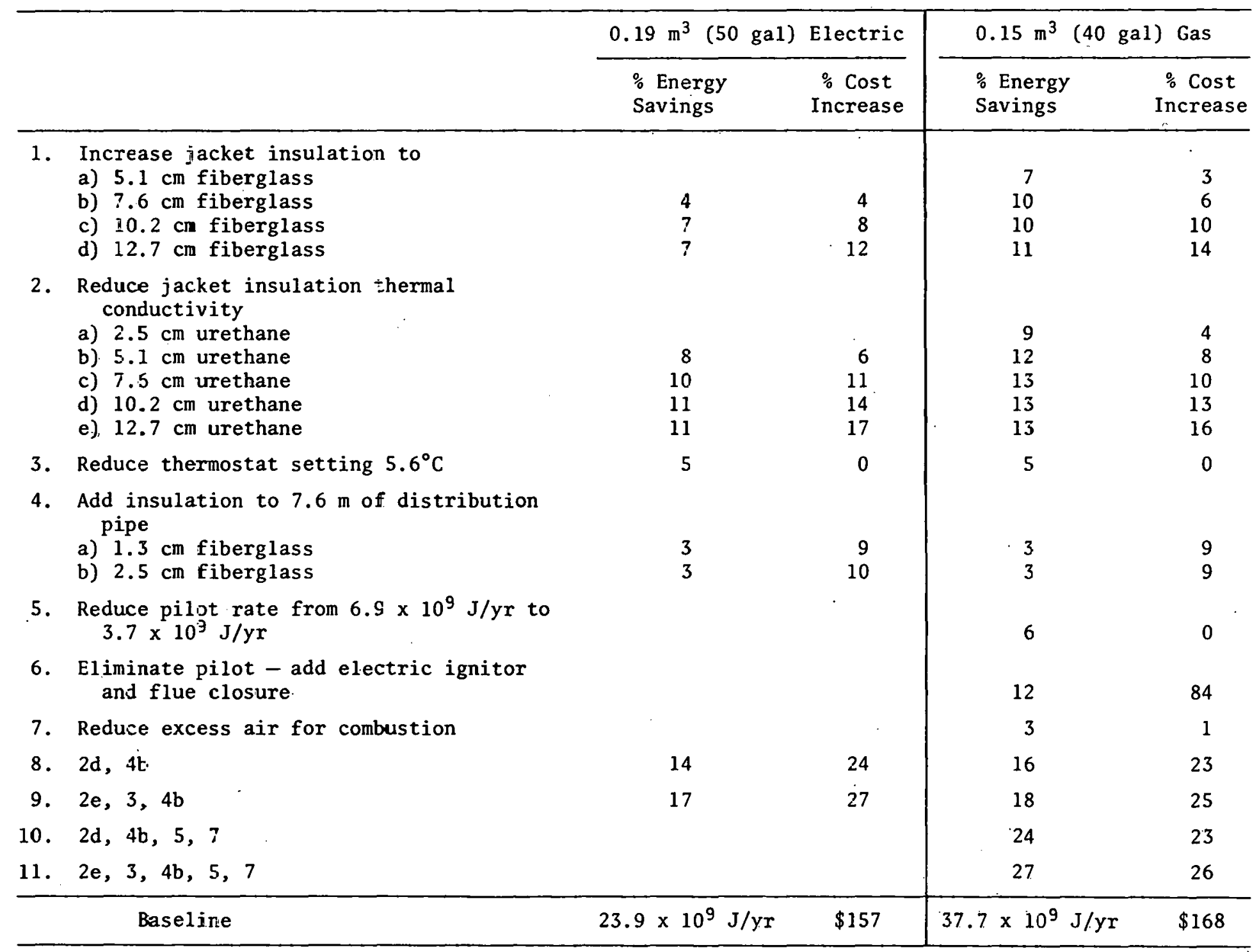




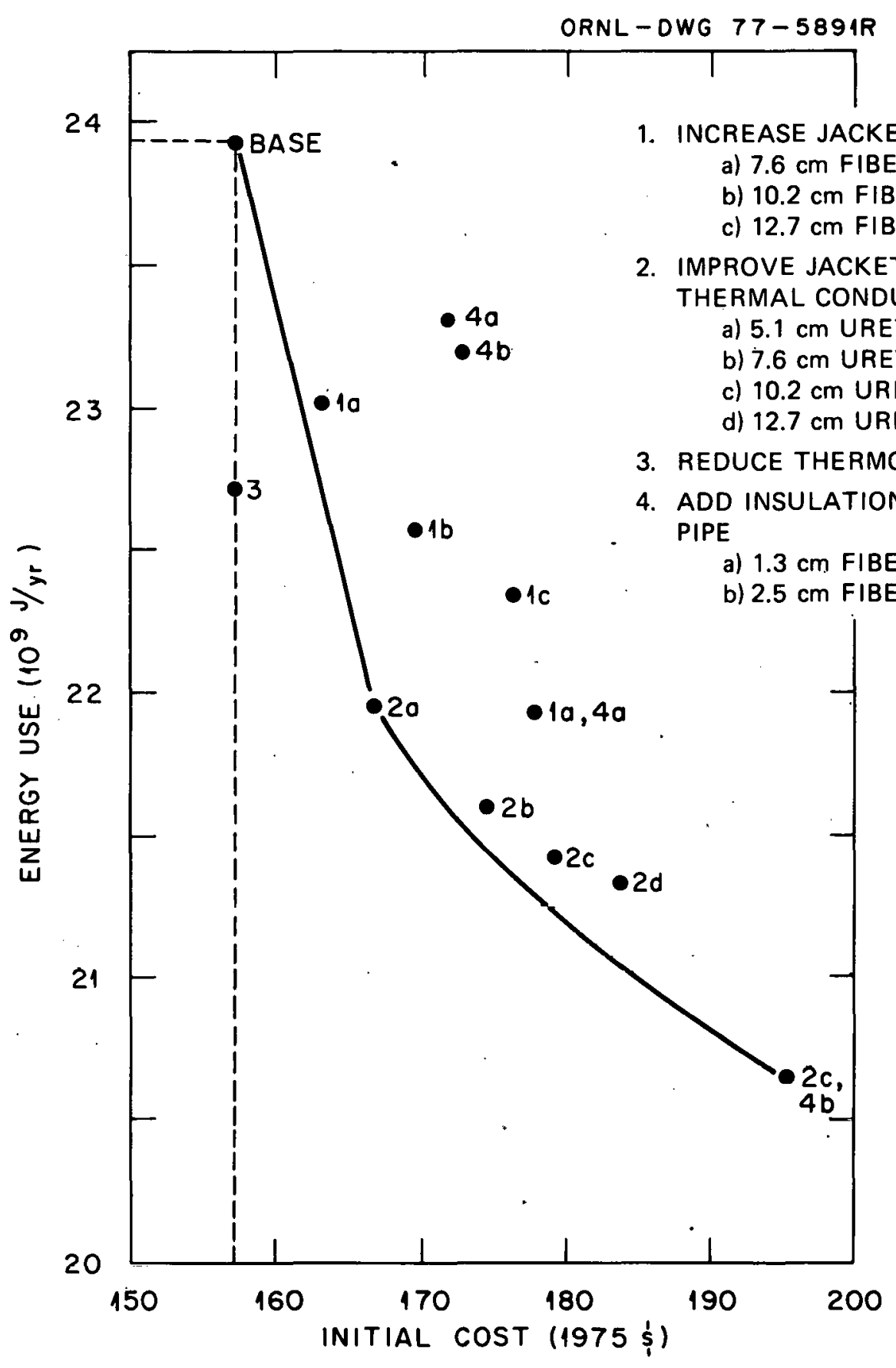

Fig. 1. Energy use vs retail price for various design changes for a $0.19 \mathrm{~m}^{3}$ (50 gal) electric water heater. 


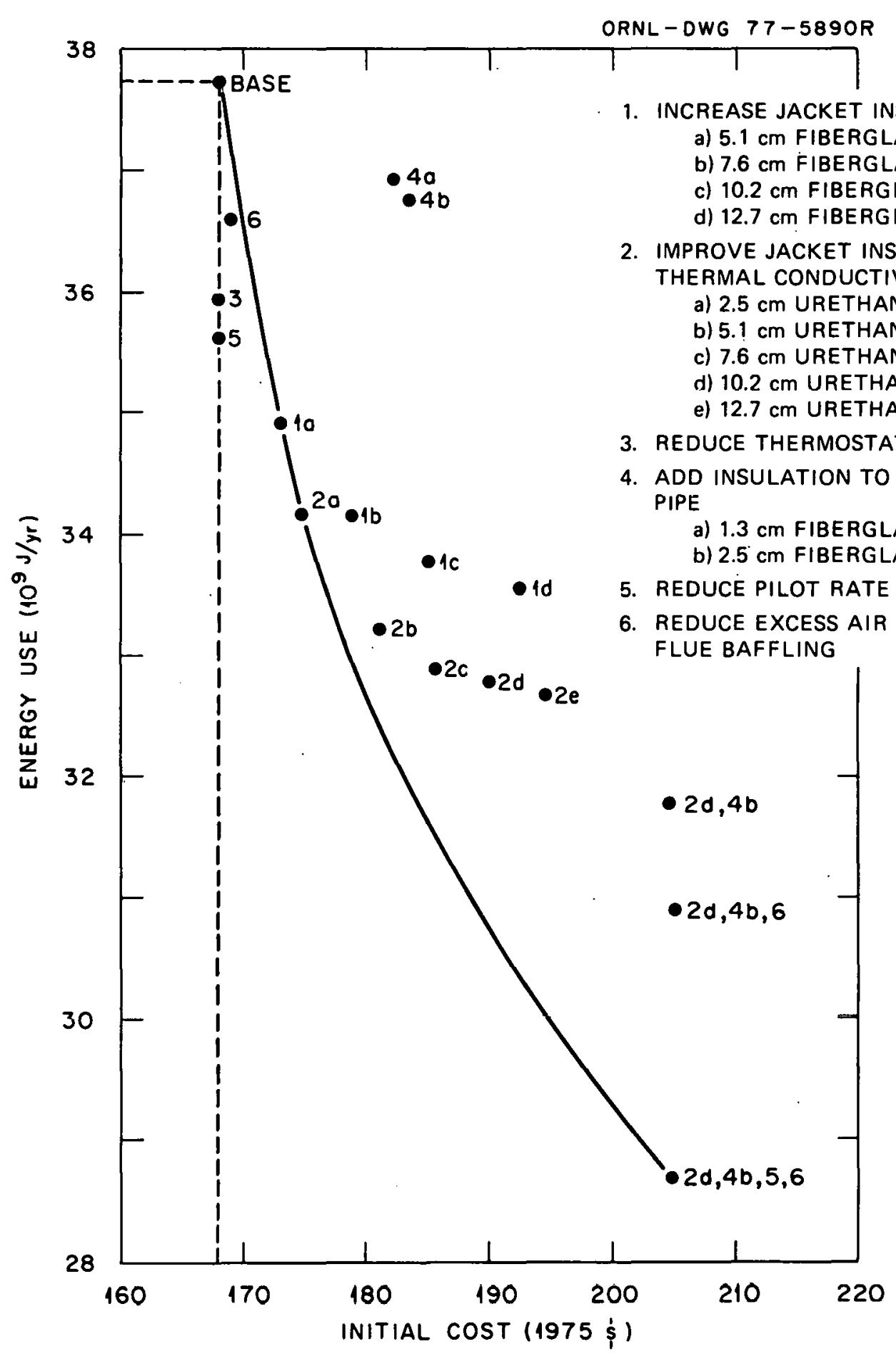

Fig. 2. Energy use vs retail price for various design changes for a $0.15 \mathrm{ml}^{3}$ (40 gal) gas water heater. 
Section 3 develops the energy model. The model evaluates heat losses from hot water due to conduction through jacket walls and distribution line; and for gas water heaters, losses due to main burner and pilot light inefficiencies. The model then determines total energy input required by water heaters as functions of the energy to heat water and each of the heat losses. Outputs from the model include all thermal loads, water heater efficiency, operating cost (based on average 1975 fuel prices*), and main burner run-time (for gas water heaters). Model predictions are compared with other estimates of water heater energy use in Section 4 .

The model is used in Section 5 to evaluate the energy and initial cost impacts of several design changes to reduce electricity or gas use. Initial cost impacts are obtained from discussions with manufacturers and reviews of related studies. The national energy and economic effects of adopting these design changes are discussed in Section 6 .

Section 7 summarizes the major features of the computer model and presents conclusions on alternative water heater designs, their cost effectiveness, and feasibility.

\section{MARKET TRENDS}

This section reviews data from the past several years on water heater ownership, purchases, initial price, lifetimes, and energy use. These data are used to define typical electric and gas water heaters analyzed later.

\footnotetext{
(gas).

${ }^{\star} 1975$ fuel prices are $\$ 8.90 / 10^{9} \mathrm{~J}$ (electricity) and $\$ 1.60 / 10^{9} \mathrm{~J}$
} 
Sales of gas water heaters have risen slightly over the past fifteen years, and sales of electric water heaters have risen sharply. In $1960,2.5$ times as many new gas water heaters as new electric water heaters were shipped. By 1975 shipments of gas and electric water heaters were approximately 2.6 and 2.2 million units/year respectively ${ }^{3}$ (see Fig. 3).

Prices of new water heaters increased steadily during recent years when measured in terms of "real" dollars." From 1960 to 1962 the price of water heaters dropped approximately 20\%. Between 1962 and 1975, gas water heater prices rose from $\$ 125$ to $\$ 168$ and electric water heater prices rose from $\$ 131$ to $\$ 157$ (see Fig. 4).

Merchandising Week ${ }^{3}$ lists manufacturers' retail prices for gas and electric water heaters. However, we found that these prices are much lower than those actually paid by consumers, based on our investigation of selling prices in the Knoxville, TN area and results presented in Consumer Reports. ${ }^{4}$ We estimate that actual prices are higher than those reported in ref. 3 by $56 \%$ for gas and $59 \%$ for electric water heaters. 1975 prices of $\$ 168(1975-\$)$ for a typical $0.15 \mathrm{~m}^{3}$ (40 gal) gas water heater and $\$ 157$ for a typical $0.19 \mathrm{~m}^{3}$ (50 gal) electric water heater are used as the basis for evaluating the design changes in Section 5 .

Most of the life-cycle costs of owning and operating a water heater are due to energy use: approximately $76 \%$ for gas and $85 \%$ for electricity. These figures are based on a 7 year lifetime for water heaters ${ }^{5,6,7}$

\footnotetext{
"Real or "constant" dollars correct for the effects of inflation.
} 


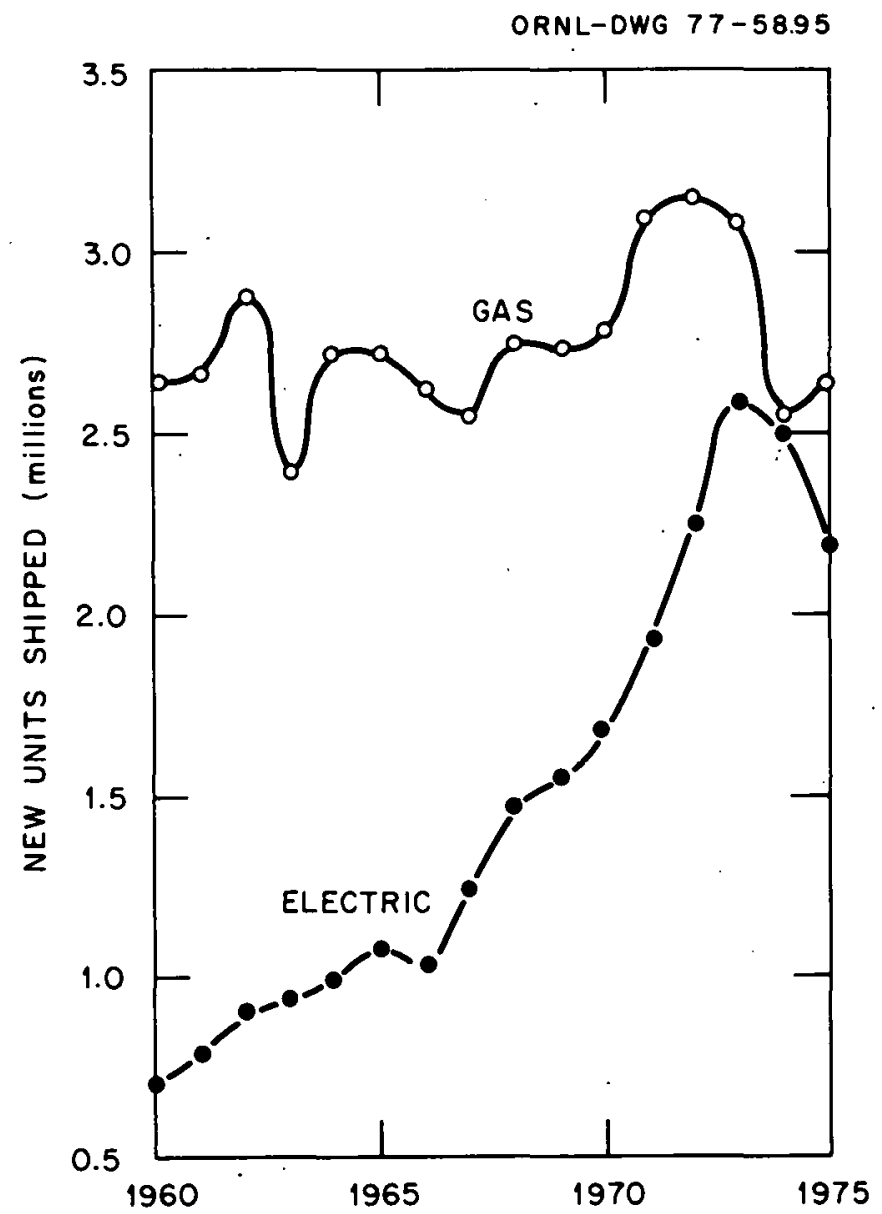

Fig. 3. Gas and electric water heatcr shipmonts, 18601875.

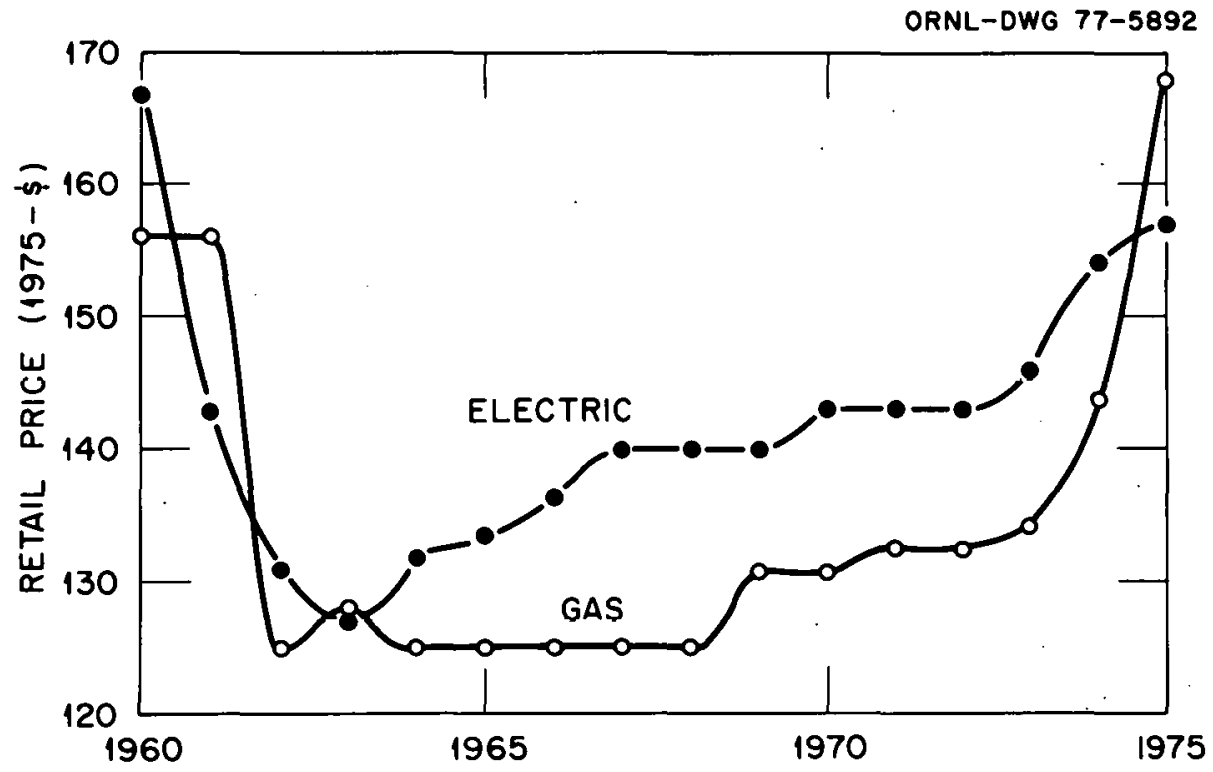

Fig. 4. Average retail price for new water heaters, 1960-1975. 
Water heater energy use depends on fuel type and operating conditions such as water usage rate, and water temperature. ${ }^{*}$ Table 3 shows several estimates of energy use for gas and electric water heaters.

Table 3. Water heater energy use estimates $\left(10^{9} \mathrm{~J} / \mathrm{m}^{3}-\right.$ day $)$

\begin{tabular}{lll}
\hline & Electric & Gas \\
\hline Lee $^{8}\left(0.27 \mathrm{~m}^{3} /\right.$ day $)$ & 0.240 & 0.398 \\
Mutch $^{6}\left(0.19 \mathrm{~m}^{3} /\right.$ day $)$ & 0.230 & 0.399 \\
Spann $^{9}\left(0.28 \mathrm{~m}^{3} /\right.$ day $)$ & 0.279 & 0.429 \\
Consumer Reports $\left(0.38 \mathrm{~m}^{3} /\right.$ day $)$. & 0.271 & 0.382 \\
This report $\left(0.27 \mathrm{~m}^{3} /\right.$ day $)$ & 0.243 & 0.383 \\
\hline
\end{tabular}

\section{ENERGY MODEL}

The control boundary considered consists of the water heater plus $7.6 \mathrm{~m}(25 \mathrm{ft})$ of hot water distribution pipe. Thus, the effect of heat lost to surrounding air on household air-conditioning and heating is not considered. Figures 5 and 6 show heat losses for electric and gas water heaters, respectively.

Electric Water Heater: The energy balance for an electric water heater is:

$$
E_{\text {in }}=E_{\text {water }}+E_{\substack{\text { jacket } \\ \text { loss }}}+E_{\substack{\text { pipe } \\ \text { loss }}}
$$

where $\mathrm{E}=$ energy flow, $\mathrm{J} / \mathrm{yr}$.

A thermostat setting of $60^{\circ} \mathrm{C}\left(140^{\circ} \mathrm{F}\right)$ and daily water usage rate of $0.27 \mathrm{~m}^{3} /$ day $(72 \mathrm{gal} / \mathrm{day})$ are used here, based on estimates from refs. 4 , $6,8,9$ and personal communication with the National Bureau of Standards. 
ORNL-DWG 77-5893

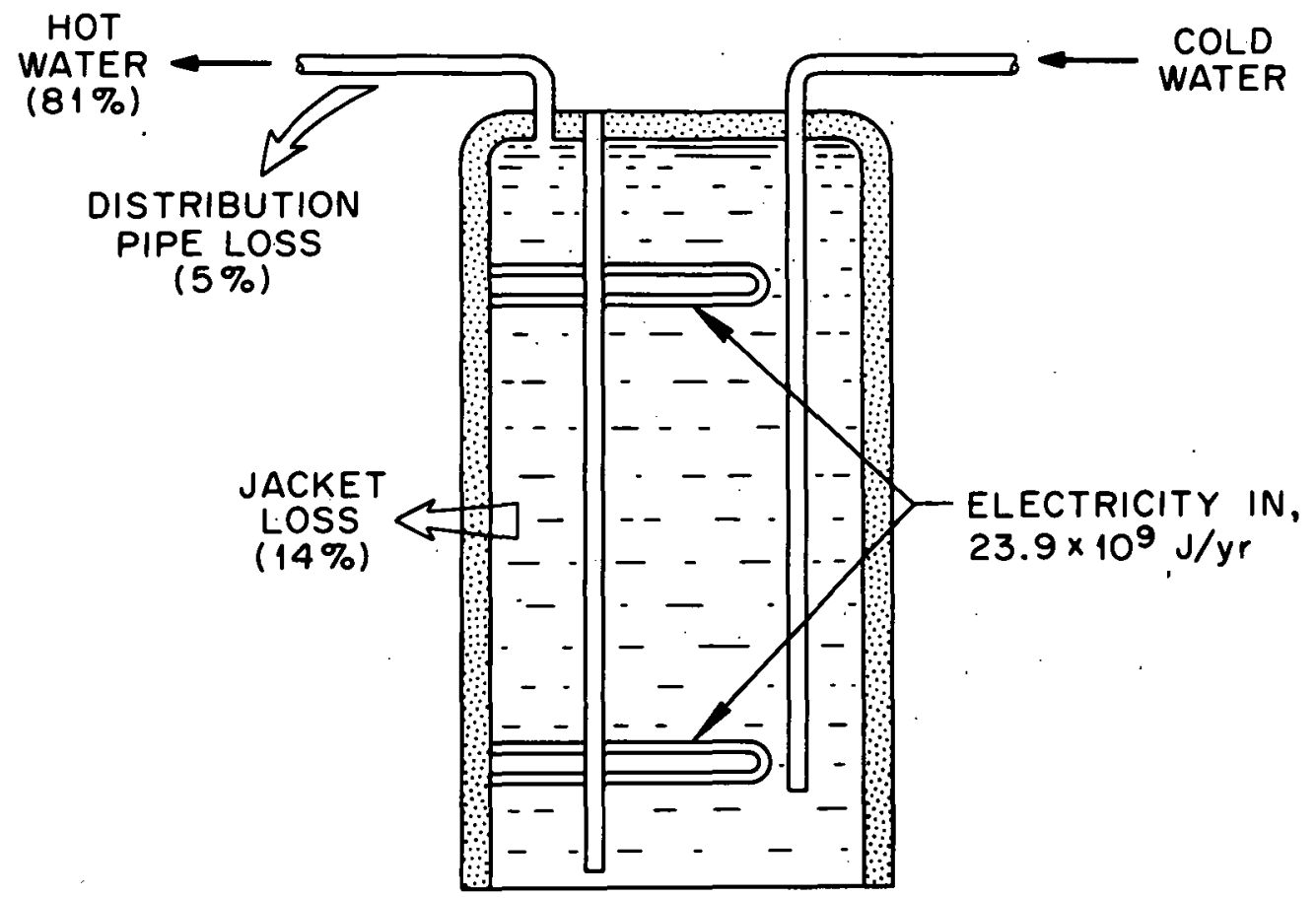

Fig. 5. Energy flows in a $0.19 \mathrm{~m}^{3}$ (50 gal) electric water heater.

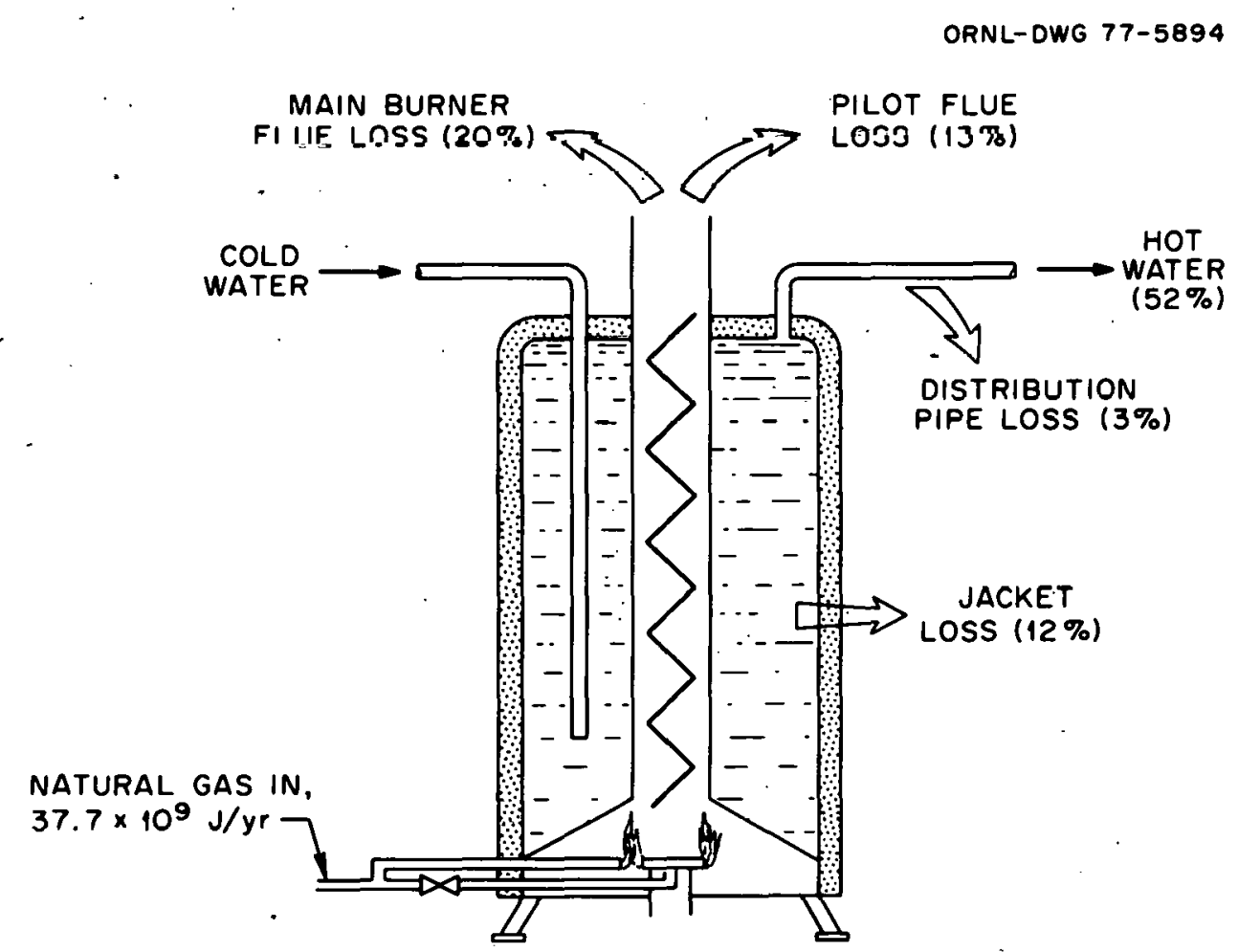

Fig. 6. Energy flows in a $0.15 \mathrm{~m}^{3}$ (40 gal) gas water heater. 
The water energy refers to the useful output (energy required to raise the inlet water temperature to the desired temperature):

$$
E_{\text {water }}=\dot{\mathrm{m}} \cdot \mathrm{c}_{\mathrm{p}} \cdot\left(\mathrm{T}_{\mathrm{w}}-\mathrm{T}_{\mathrm{wi}}\right) \cdot 365
$$

where

$$
\begin{aligned}
\dot{\mathrm{m}} & =\text { water use, } \mathrm{m}^{3} / \text { day } \\
\mathrm{c}_{\mathrm{p}} & =\text { specific heat of water, } \mathrm{J} / \mathrm{m}^{3}-{ }^{\circ} \mathrm{C} \\
\mathrm{T}_{\mathrm{w}} & =\text { temperature of hot water, }{ }^{\circ} \mathrm{C} \\
\mathrm{T}_{\mathrm{wi}} & =\text { inlet water temperature, }{ }^{\circ} \mathrm{C}
\end{aligned}
$$

The water heater efficiency is:

$$
\eta=E_{\text {water }} / E_{\text {in }}
$$

The efficiency of a $0.19 \mathrm{~m}^{3}$ (50 gal) electric water heater is $81 \%$ (see Appendix C) .

Jacket loss is determined from the heat conduction equation:

$$
\underset{\substack{\text { jacket } \\ \text { loss }}}{E_{\text {a }}}=U \cdot A \cdot\left(T_{w}-T_{\text {amb }}\right) \cdot 8760
$$

where

$$
\begin{aligned}
\mathrm{U} & =\text { overall heat transfer coefficient, } \mathrm{J} / \mathrm{m}^{2}-\mathrm{hr}-{ }^{\circ} \mathrm{C} \\
\mathrm{A} & =\text { surface area of tank, } \mathrm{m}^{2} \\
\mathrm{~T}_{\mathrm{amb}} & =\text { ambient temperature, }{ }^{\circ} \mathrm{C}
\end{aligned}
$$


Most manufacturers provide electric water heaters with $5.1 \mathrm{~cm}$ (2 in.) of fiberglass insulation. Thus, jacket loss is $14 \%$ (see Fig. 5) of energy input.

The main loss of energy in the distribution pipe is due to cool down of water during periods of no water withdrawal:

$$
\mathrm{E}_{\text {pipe }}=Q^{\prime} \cdot \mathrm{L} \cdot\left(\mathrm{T}_{\mathrm{w}}-\mathrm{T}_{\mathrm{amb}}\right)
$$

where

$$
\begin{aligned}
\mathrm{Q}^{\prime} & =\text { annual heat loss per meter of pipe per }{ }^{\circ} \mathrm{C}, \mathrm{J} / \mathrm{yr}-\mathrm{m}-{ }^{\circ} \mathrm{C} \\
\mathrm{L} & =\text { length of hot water line, } \mathrm{m}
\end{aligned}
$$

Quinn $^{8}$ reports that for bare tarnished $1.3 \mathrm{~cm}(0.5 \mathrm{in.})$ copper pipe, an average family hot water usage schedule gives a transient heat loss of $3.7 \times 10^{6} \mathrm{~J} / \mathrm{yr}-\mathrm{m}-{ }^{\circ} \mathrm{C}$. Of the energy input to the average electric water heater, 5\% (see Fig. 5) is lost through the distribution line (for $\mathrm{L}=7.6 \mathrm{~m})$.

Gas Water Heater: The energy balance for a gas water heater is:

$$
E_{\text {in }}=E_{\text {water }}+E_{\substack{\text { jacket } \\ \text { loss }}}+\underset{\substack{\text { pipe } \\ \text { loss }}}{E_{\text {loss }}}+E_{\text {burner }}+E_{\text {pilot }}
$$

where $E_{\text {water, }}, E_{\text {jacket, }}$ and $E_{\text {pipe }}$ are found using equations (2), (4),

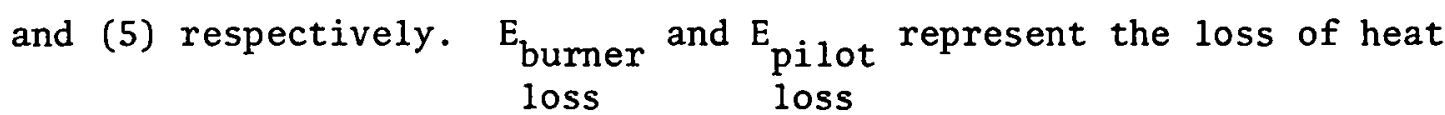
out the flue. The pilot operates continuously; however, the main burner operates only when the thermostat detects a hot water temperature below 
a specific temperature level. Therefore, flue loss and heat input are functions of main burner run-time.

Based on a main burner rate of $0.28 \times 10^{9} \mathrm{~J} / \mathrm{hr}-\mathrm{m}^{3}$ (communications with several manufacturers), the main burner loss is:

$$
\mathrm{E}_{\substack{\text { burner } \\ \text { loss }}}=\left(0.28 \times 10^{9}\right) \cdot \mathrm{V} \cdot \mathrm{t} \cdot\left(1-\dot{\eta}_{\mathrm{b}}\right)
$$

where

$$
\begin{aligned}
V & =\text { volume of tank, } \mathrm{m}^{3} \\
t & =\text { hours per year of main burner operation } \\
n_{b} & =\text { main burner efficiency }
\end{aligned}
$$

Based on experimental data, the main burner efficiency $\left(\eta_{b}\right)$ is $75 \% 9$ (see Appendix B) .

Data from several manufacturers give a pilot rate between $0.74 \times 10^{6}$ and $0.82 \times 10^{6} \mathrm{~J} / \mathrm{hr}$. Assuming a pilot rate of $0.79 \times 10^{6} \mathrm{~J} / \mathrm{hr}$, the pilot loss is

$$
\underset{\substack{\text { pilot } \\ \text { loss }}}{E}\left(0.79 \times 10^{6}\right)\left[\left(1-\eta_{b}\right) t+\left(1-\eta_{p}\right)(8760-t)\right]
$$

where $n_{p}=$ pilot efficiency. The pilot efficiency (percent of heat from the pilot which actually heats water) is $22 \% .10$

The energy input to the water heater $\left(E_{i n}\right)$ is a function of main burner run-time and main burner and pilot rates: 


$$
E_{\text {in }}=\left(0.28 \times 10^{9}\right) \cdot V \cdot t+\left(0.79 \times 10^{6}\right) \cdot 8760
$$

Substitution into (6) gives the main burner run-time, which for an average $0.15 \mathrm{~m}^{3}$ (40 gal) gas water heater is $737 \mathrm{hr} / \mathrm{yr}$.

The efficiency of the gas water heater is found from equation (3): $52 \%$ for a $0.15 \mathrm{~m}^{3}$ water heater.

Computer outputs for the electric and gas reference water heaters are given in Appendix $C$.

\section{VALIDATION OF ENERGY MODEL}

Our model was used to simulate water heater size, type, and operating conditions for several studies, as shown in Tables 4 and 5.

Table 4. Comparison of energy model with related studies for electric water heaters

\begin{tabular}{|c|c|c|c|c|c|c|}
\hline & \multicolumn{2}{|c|}{$\begin{array}{c}\text { Unit } 1^{a} \\
\left(10^{9} \mathrm{~J} / \mathrm{yr}\right)\end{array}$} & \multicolumn{2}{|c|}{$\begin{array}{c}\text { Unit } 2^{b} \\
\left(10^{9} \mathrm{~J} / \mathrm{yr}\right)\end{array}$} & \multicolumn{2}{|c|}{$\begin{array}{c}\operatorname{lnit} .3^{c} \\
\left(10^{9} \mathrm{~J} / \mathrm{yr}\right)\end{array}$} \\
\hline & Model & Mutch & Model & Spann & Mode1 & Lee \\
\hline $\begin{array}{l}\text { Useful energy } \\
\text { Jacket loss }\end{array}$ & $\begin{array}{r}12.5 \\
3.4\end{array}$ & $\begin{array}{r}12.5 \\
3.4\end{array}$ & $\begin{array}{r}22.9 \\
3.8\end{array}$ & $\begin{array}{r}22.9 \\
.6 .0\end{array}$ & $\begin{array}{r}19.5 \\
4.3\end{array}$ & $\begin{array}{r}19.6 \\
4.1\end{array}$ \\
\hline Total input & 15.9 & 15.9 & 26.7 & 28.9 & 23.8 & 23.7 \\
\hline Efficiency & $78.8 \%$ & $78.8 \%$ & $85.8 \%$ & $79.1 \%$ & $82.0 \%$ & $83.0 \%$ \\
\hline
\end{tabular}

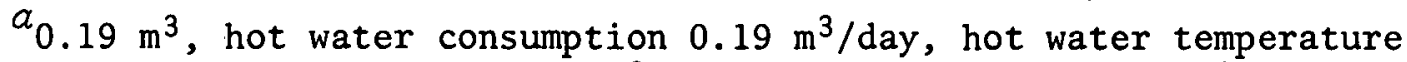
$60^{\circ} \mathrm{C}$, inlet water temperature $12.8^{\circ} \mathrm{C}$, ambient temperature $21.1^{\circ} \mathrm{C}$, jacket insulation thickness $0.051 \mathrm{~m}$.

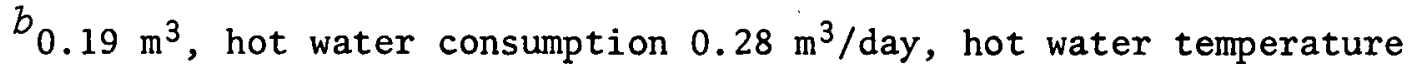
$65.6^{\circ} \mathrm{C}$, inlet water temperature $12.8^{\circ} \mathrm{C}$, ambient temperature $21.1^{\circ} \mathrm{C}$, jacket insulation thickness $0.051 \mathrm{~m}$.

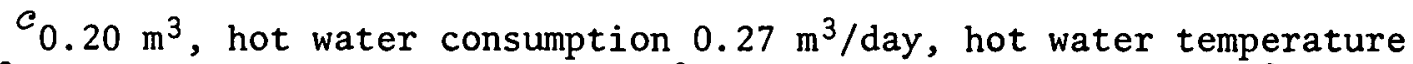
$62.8^{\circ} \mathrm{C}$, inlet water temperature $15.6^{\circ} \mathrm{C}$, ambient temperature $21.1^{\circ} \mathrm{C}$, jacket insulation thickness $0.045 \mathrm{~m}$. 
Table 5. Comparison of energy model with related studies for gas water heaters

\begin{tabular}{|c|c|c|c|c|c|c|}
\hline & \multicolumn{2}{|c|}{$\begin{array}{l}\text { Unit } 1^{\alpha} \\
\left(10^{9} \mathrm{~J} / \mathrm{yr}\right)\end{array}$} & \multicolumn{2}{|c|}{$\begin{array}{c}\text { Unit } 2^{b} \\
\left(10^{9} \mathrm{~J} / \mathrm{yr}\right)\end{array}$} & \multicolumn{2}{|c|}{$\begin{array}{c}\text { Unit } 3^{c} \\
\left(10^{9} \mathrm{~J} / \mathrm{yr}\right)\end{array}$} \\
\hline & Mode1 & Mutch & Model & Spann & Model & Lee \\
\hline Useful energy & 12.5 & 12.5 & 22.9 & 22.9 & 19.5 & 19.6 \\
\hline Jacket loss & 4.4 & 9.6 & 4.9 & 7.0 & 6.8 & 4.8 \\
\hline $\begin{array}{l}\text { Flue loss: } \\
\text { main burner } \\
\text { pilot }\end{array}$ & $\begin{array}{l}6.5 \\
5.2\end{array}$ & $\begin{array}{l}3.3 \\
2.1\end{array}$ & $\begin{array}{r}10.0 \\
5.0\end{array}$ & $\begin{array}{l}8.3 \\
6.3\end{array}$ & $\begin{array}{l}9.5 \\
4.8\end{array}$ & $\begin{array}{l}8.9 \\
5.9\end{array}$ \\
\hline Total input & 28.6 & 27.5 & 42.8 & 44.5 & 40.6 & 39.2 \\
\hline Efficiency & $43.7 \%$ & $45.5 \%$ & $53.5 \%$ & $51.4 \%$ & $48.0 \%$ & $50.0 \%$ \\
\hline
\end{tabular}

$a_{0.15 \mathrm{~m}^{3}}$, hot water consumption $0.19 \mathrm{~m}^{3} /$ day, hot water temperature $60^{\circ} \mathrm{C}$, inlet water temperature $12.8^{\circ} \mathrm{C}$, ambient temperature $21.1^{\circ} \mathrm{C}$, jacket insulation thickness $0.025 \mathrm{~m}$, main burner rate $0.279 \times 10^{9} \mathrm{~J} / \mathrm{hr}-\mathrm{m}^{3}$, pilot rate $7.913 \times 10^{6} \mathrm{~J} / \mathrm{hr}$.

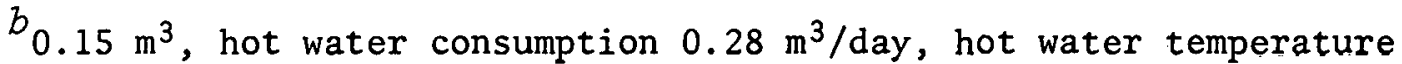
$60^{\circ} \mathrm{C}$, inlet water temperature $12.8^{\circ} \mathrm{C}$, ambient temperature $21.1^{\circ} \mathrm{C}$, jacket insulation thickness $0.025 \mathrm{~m}$, main burner rate $0.279 \times 10^{9} \mathrm{~J} / \mathrm{hr}^{3} \mathrm{~m}^{3}$, pilot rate $7.913 \times 10^{6} \mathrm{~J} / \mathrm{hr}$.

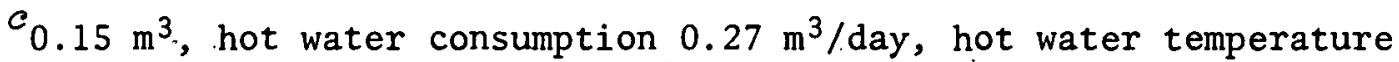
$62.8^{\circ} \mathrm{C}$, inlet water temperature $19.6^{\circ} \mathrm{C}$, ambient temperature $21.1^{\circ} \mathrm{C}$, jacket insulation thickness $0.019 \mathrm{~m}$, main burner rate $0.314 \times 10^{9} \mathrm{~J} / \mathrm{hr}-\mathrm{m}^{3}$, pilot rate $7.385 \times 10^{6} \mathrm{~J} / \mathrm{hr}$ (jacket loss in Lee estimate includes floor loss).

Predictions of water heater energy use computed with the energy model agree well with estimates from related studies.

Table 4 compares model results with those of Mutch, 6 Spann, 10 and Lee $^{9}$ for electric water heaters. The model matches Mutch's estimates exactly for all energy flows. Estimates of useful energy are essentially the same as the Spann and Lee results, but jacket loss estimates from the model are slightly higher than Spann's and slightly lower than Lee's. 
Table 5 compares model results with those of Mutch, Spann, and Lee for gas water heaters. Again, the energy model estimates the same useful energy flows as each study. Jacket and flue losses predicted by the model are slightly different from the other studies, but the model estimates approach the averages of the various studies. Total input and efficiency estimates are in good agreement.

\section{ENERGY-CONSERVING DESIGN OPTIONS}

Several energy-conserving designs are evaluated with respect to both energy saved and changes in retail price for electric and gas water heaters (Appendix D). These options include: 1) increase jacket insulation thickness, 2) reduce jacket insulation thermal conductivity, 3) reduce thermostat setting, and 4) add insulation to the distribution pipe. The efficiency of a gas water heater (52\%) is lower than that of an electric water heater $(81 \%)$ because of flue losses. Additional design changes investigated for gas water heaters include: 1) reduce pilot rate, 2) eliminate pilot, add electric ignitor and flue closure, and 3) reduce excess air for combustion (increase flue baffling). Figures 1 and 2 show energy use versus retail price for these design changes for a $0.19 \mathrm{~m}^{3}$ (50 gal) electric water heater and a $0.15 \mathrm{~m}^{3}$ (40 gal) gas water heater.* .

Increase Jacket Insulation Thickness: One of the largest heat losses in both electric and gas waters heaters is through jacket walls.

\footnotetext{
* Other design changes for gas water heaters not included in this study due to lack of data include: 1) powered burner to increase main burner and pilot efficiencies, and 2) heat trap to reduce pilot losses during standby.
} 
Electric water heaters generally have $5.1 \mathrm{~cm}$ (2 in.) of fiberglass jacket insulation; $14 \%$ of energy input to the water heater is lost through the jacket. Gas water heaters generally have only $2.5 \mathrm{~cm}$ ( 1 in.) of insulation; $12 \%$ of energy input is lost through the jacket. An increase in jacket insulation thickness will reduce this loss significantly. Energy savings are determined by substituting new values for the overall heat transfer coefficient and the tank surface area into equation (4), and then solving the energy equations. Table 6 shows the energy savings, added cost, 9 and payback period for increased insulation of electric and gas water heaters.*

The addition of jacket insulation is limited, because the water heater must remain narrow enough in its shipping carton to fit through the average doorway. Therefore, the insulation thickness should not exceed $10.2 \mathrm{~cm}$. Table 6 shows that an increase in insulation thickness beyond $10.2 \mathrm{~cm}$ yields only slight energy savings.

Improve jacket insulation thermal conductivity: Foamed-in-place urethane provides better insulation than fiberglass because of its lower thermal conductivity $\left(\mathrm{k}_{\text {urethane }}=70.0 \mathrm{~J} / \mathrm{m}-\mathrm{hr}-{ }^{\circ} \mathrm{C}, \mathrm{k}_{\text {fiberglass }}=161.0\right.$ $\mathrm{J} / \mathrm{m}-\mathrm{hr}-{ }^{\circ} \mathrm{C}$ ). ${ }^{11}$ Table 7 shows energy savings, added cost, and payback period for use of urethane foam as jacket insulation. ${ }^{\dagger}$

\footnotetext{
*Insulation can also be added to existing units. Commercially available insulation kits that cost $\$ 16$ provide $3.8 \mathrm{~cm}$ (1.5 in.) of vinyl-backed fiberglass insulation for the top and sides of the water heater, ${ }^{9}$ and can reduce energy use $5 \%$ for electric and gas water heaters.

${ }^{\dagger}$ As urethane ages, its conductivity will increase because freon in the insulation will gradually escape. Also, urethane may cause safety problems because of its flammability and may corrode unless specially treated.
} 
Table 6. Energy and economic effects of increased jacket insulation thickness

\begin{tabular}{|c|c|c|c|c|c|c|}
\hline \multirow[b]{2}{*}{$\begin{array}{l}\text { Insulation } \\
\text { thickness } \\
\text { (cm) }\end{array}$} & \multicolumn{3}{|c|}{ Electric } & \multicolumn{3}{|c|}{ Gas } \\
\hline & $\begin{array}{l}\text { Energy } \\
\text { savings }\end{array}$ & $\begin{array}{c}\text { Added } \\
\text { cost } \\
(1975-\$)\end{array}$ & $\begin{array}{l}\text { Payback } \\
\text { period } a \\
(y r)\end{array}$ & $\begin{array}{l}\text { Energy } \\
\text { savings }\end{array}$ & $\begin{array}{c}\text { Added } \\
\text { cost } \\
(1975-\$)\end{array}$ & $\begin{array}{c}\text { Payback } \\
\text { period } \\
(y r)\end{array}$ \\
\hline 5.1 & $\ldots$ & $\ldots$ & $\ldots$ & $7 \%$ & 4.9 & 1.1 \\
\hline 7.6 & $4 \%$ & 6.1 & 0.7 & $10 \%$ & 10.9 & 1.9 \\
\hline 10.2 & $7 \%$ & 12.1 & 1.0 & $10 \%$ & 17.0 & 2.7 \\
\hline 12.7 & $7 \%$ & 19.4 & 1.4 & $11 \%$ & 24.2 & 3.6 \\
\hline
\end{tabular}

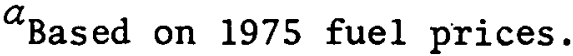

Table 7. Energy and economic effects of reduced jacket insulation thermal conductivity (urethane foam)

\begin{tabular}{|c|c|c|c|c|c|c|}
\hline \multirow[b]{2}{*}{$\begin{array}{l}\text { Insulation } \\
\text { thickness } \\
\text { (cm) }\end{array}$} & \multicolumn{3}{|c|}{ Electric } & \multicolumn{3}{|c|}{ Gas } \\
\hline & $\begin{array}{l}\text { Energy } \\
\text { savings }\end{array}$ & $\begin{array}{c}\text { Added } \\
\text { cost } \\
(1975-\$)\end{array}$ & $\begin{array}{l}\text { Payback } \\
\text { period } \\
\text { (yr) }\end{array}$ & $\begin{array}{l}\text { Energy } \\
\text { savings }\end{array}$ & $\begin{array}{c}\text { Added } \\
\text { cost } \\
(1975-\$)\end{array}$ & $\begin{array}{l}\text { Payback } \\
\text { period } \\
(y r)\end{array}$ \\
\hline 2.5 & $\ldots$ & $\ldots$ & $\ldots$ & $9 \%$ & 6.8 & 1.2 \\
\hline 5.1 & $8 \%$ & 9.5 & 0.5 & $12 \%$ & 13.0 & 1.8 \\
\hline 7.6 & $10 \%$ & 17.5 & 0.8 & $13 \%$ & 17.5 & 2.3 \\
\hline 10.2 & $11 P_{0}$ & 22.0 & 1.0 & $13 \%$ & 22.0 & 2.8 \\
\hline 12.7 & $11 \%$ & 26.5 & 1.1 & $13 \%$ & 26.5 & 3.3 \\
\hline
\end{tabular}

Another alternative for reducing thermal conductivity is installation of "double density" fiberglass with $\mathrm{k}=98.6 \mathrm{~J} / \mathrm{m}-\mathrm{hr}-{ }^{\circ} \mathrm{C} .10$ While this provides an improvement in energy savings over single density fiberglass, it is not as effective as urethane foam. From a cost perspective, double density fiberglass and urethane foam are approximately equal.

Reduce thermostat setting: A thermostat setback from 60 to $54.4^{\circ} \mathrm{C}$ $\left(10^{\circ} \mathrm{F}\right.$ reduction) is an effective design option because: (1) substantial energy savings for both electric and gas water heaters are possible, 
(2). the thermostat is easily adjusted, and (3) no additional cost is incurred to either the homeowner or the manufacturer (assuming tank volume remains unchanged).

Energy savings for electric and gas water heaters are estimated assuming that the quantity of hot water consumed per day is a function of water temperature. A constant volume is required for some hot water uses regardless of temperature (dishwashers and clothes washers) and constant energy (joule) is required for others (showers, baths, personal use). Assuming that $25 \%$ of hot water demand is for fixed volume and $75 \%$ for fixed energy, ${ }^{9}$ energy savings are calculated by lowering the temperature of hot water $T_{w}$, and increasing water use $\dot{m}$ :

$$
\dot{\mathrm{m}}_{\mathrm{new}}=0.25 \dot{\mathrm{m}}_{\mathrm{old}}+0.75 \dot{\mathrm{m}}^{\prime}
$$

where

$$
\left.\dot{\mathrm{m}}^{\prime}=\underset{\substack{\text { water } \\ \text { old }}}{\mathrm{E}_{\text {f }}} /\left[\mathrm{c}_{\mathrm{p}} \underset{\text { new }}{\left(\mathrm{T}_{\mathrm{w}}\right.}-\mathrm{T}_{\text {wi }}\right) 365\right]
$$

From equations (2) and (4), energy required to heat the water and energy lost through jacket walls will decrease. This lowers energy input to the water heater. A reduction of $5.6^{\circ} \mathrm{C}\left(10^{\circ} \mathrm{F}\right)$ will decrease energy consumption for electric and gas water heaters $5 \%$. A reduction of $11.2^{\circ} \mathrm{C}$ $\left(20^{\circ} \mathrm{F}\right)$ cuts energy use $10 \%$ and $9 \%$ respectively. ${ }^{*}$

\footnotetext{
* Families with large hot water demands might need a larger water heater to compensate for reduced water temperatures. This would increase water heater costs about $\$ 20$ for a $5.6^{\circ} \mathrm{C}$ reduction. Also, lower water t.emperature may cause problems with automatic dishwashor uso rclated to bacteria, cleanliness, and spotting.
} 
Add insulation to distribution line: Heat lost through the hot water distribution line during periods of no water withdrawal can be reduced by adding fiberglass pipe insulation. The insulation is easy to install, so labor costs are low. Insulation dealers carry pipe insulation, which comes in preformed lengths with a protective exterior jacket and water barrier.

The transient heat loss through the distribution pipe (bare tarnished $1.3 \mathrm{~cm}$ copper pipe) is $3.68 \times 10^{6} \mathrm{~J} / \mathrm{yr}-\mathrm{m}-{ }^{\circ} \mathrm{C}$, based on an average family water usage schedule given by Quinn. ${ }^{8}$ ASHRAEll states that the steady-state heat loss through this pipe is $14.81 \times 10^{6}$ $\mathrm{J} / \mathrm{yr}-\mathrm{m}-{ }^{\circ} \mathrm{C}$, so an appropriate transient-to-steady-state adjustment factor is obtained and the transient heat losses with 1.3 and $2.5 \mathrm{~cm}$ fiberglass are determined (see Table 8). Values for the steady-state heat loss for added insulation were obtained from Brennon Insulation Co. of Knoxville, TN.

The energy savings due to added insulation are determined from equation (5), in which the new value of $Q^{\prime}$ is substituted from Table 8 . For either an electric or gas water heater, addition of 1.3 or $2.5 \mathrm{~cm}$ of fiberglass insulation will save $3 \%$ of the energy input. The cost of the $1.3 \mathrm{~cm}$ insulation is $\$ 1.42 / \mathrm{m}(1975-\$)$, based on communication with several insulation retail outlets, so the cost to insulate $7.6 \mathrm{~m}$ is $\$ 10.8$ plus $\$ 3.5$ labor. The $2.5 \mathrm{~cm}$ insulation retails for $\$ 1.62 / \mathrm{m}$, so insulation for $7.6 \mathrm{~m}$ of distribution line is $\$ 12.3$ plus $\$ 3.5$ labor (see Table 9). 
Table 8. Heat loss through tarnished $1.3 \mathrm{~cm}$ distribution pipe

\begin{tabular}{|c|c|c|}
\hline 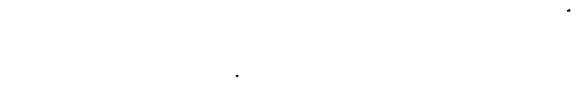 & $\begin{array}{r}\text { Steady-State } \\
\left(10^{6}\right.\end{array}$ & $\begin{array}{l}\text { Transient ( } \\
\left.\mathrm{J} / \mathrm{yr}-\mathrm{m}-{ }^{\circ} \mathrm{C}\right)\end{array}$ \\
\hline Bare pipe & 14.81 & 3.68 \\
\hline Pipe with $1.3 \mathrm{~cm}$ fiberglass & 6.24 & 1.55 \\
\hline Pipe with $2.5 \mathrm{~cm}$ fiberglass & 4.68 & 1.16 \\
\hline
\end{tabular}

Table 9. Energy and economic savings from added fiberglass pipe insulation to $7.6 \mathrm{~m}$ distribution line

\begin{tabular}{cccc|cc}
\hline & & \multicolumn{2}{c|}{ Electric } & \multicolumn{2}{c}{ Gas } \\
$\begin{array}{c}\text { Fibergiass } \\
\text { insulation } \\
(\mathrm{cm})\end{array}$ & $\begin{array}{c}\text { Added } \\
\text { cost } \\
(1975-\$)\end{array}$ & $\begin{array}{c}\text { Energy } \\
\text { savings }\end{array}$ & $\begin{array}{c}\text { Payback } \\
\text { period } \\
(\mathrm{yr})\end{array}$ & $\begin{array}{c}\text { Energy } \\
\text { savings }\end{array}$ & $\begin{array}{c}\text { Payback } \\
\text { period } \\
(\mathrm{yr})\end{array}$ \\
\hline 1.3 & 14.3 & $3 \%$ & 2.5 & $3 \%$ & 10.8 \\
2.5 & 15.8 & $3 \%$ & 2.4 & $3 \%$ & 10.0 \\
\hline
\end{tabular}

Reduce pilot rate: The pilot light in a gas water heater operates continuously and serves as a heat source to tank water and an ignitor for the main burner. However, when the main burner is off, only $22 \%$ of the pilot energy heats water; ${ }^{9}$ the remainder escapes up the flue. The energy lost by the pilot is decreased if the pilot rate is reduced. This is accomplished by reducing the pilot orifice area.

Reduction of pilot rate is limited by the instability of pilot flames which are too small, since drafts or gas supply pressure changes could extinguish them. $\Lambda$ minimum pilot rate of $3.7 \times 10^{9} \mathrm{~J} / \mathrm{yr}$ is recommended by a leading manufacturer based on their experimental data. Substituting this new pilot rate into equation (8) and solving for the pilot loss and total energy input yields an energy saving of $6 \%$. No change in retail price occurs from this design change. 
Eliminate pilot--add electric ignitor and flue closure: Flue losses during standby for a gas water heater account for $13 \%$ of energy input. If an electric ignitor is used in place of the pilot and no damper is used, flue losses from the pilot are eliminated, but the tank hot water will continue to lose heat to the cooler gases in the flue, which then flow up the stack. Thus, the energy saved by merely replacing the pilot with an electric ignitor is negligible.

When an electric ignitor and automatic damper are installed together, the flue loss is eliminated because the damper prevents hot air from escaping during standby.

When the temperature of the water drops below a certain level, the automatic damper opens and the electric ignitor ignites the main burner. Should the damper fail to open upon ignition of the main burner, combustion gases (including $\mathrm{CO}$ ) would leak into the house. A detection device or sensor should be installed to assure damper opening before the main burner is ignited.

Energy savings for electric ignitor and flue damper are determined by assuming a pilot rate of $0.0 \mathrm{~J} / \mathrm{yr}$ in equations (8) and (9). Solving equation (6) for the new energy input shows a saving of $12 \%$. Lee ${ }^{9}$ estimates an increase in retail cost of $\$ 101$ for parts and $\$ 40$ for installation for an automatic ignition with flue closure. This nearly doubles the retail cost of the water heater, and results in a 19.6 year payback period. Because the payback period is so long, this is not a cost-effective design change.

Reduce excess air for combustion (increase flue baffling): The loss of heat up the flue of a gas water heater is proportional to the amount 
of excess air for combustion, because this air is heated during combustion and then escapes up the stack. By restricting air flow in the flue, the amount of excess air is reduced and the flue gas exit temperature drops. This is achieved by increasing flue baffling or repositioning the baffling in a manner that hinders air flow. The amount of baffling that can be added to the flue is limited, because too much air flow restriction would eliminate the pressure difference (necessary for natural draft) between entering air and exiting gas, and combustion gases would leak into the surrounding air. For a $244^{\circ} \mathrm{C}\left(440^{\circ} \mathrm{F}\right)$ temperature difference* between flue exit and ambient temperature, and a $50 \%$ excess air rate, the percent of energy lost up the flue is $23 \%$ (see Appendix B). Substituting $\left(1-\eta_{b}\right)=0.23$ into equations (7) and (8) and solving equation (6) for the new energy input, indicates a savings of $3 \%$. The added cost of increased flue baffling is $\$ 1.15 .^{9}$ The payback period is 0.6 year.

\section{NATIONAL EFFECTS OF REDUCING WATER HEATER ENERGY USE}

We used the UKNL residential energy use simulation model ${ }^{1}$ to evaluate the effects on national energy use and household economics of adopting combinations of water heater design options discussed in the preceding section.

We ran three cases with the simulation model. In the first, we assumed that water heater energy use per unit remained constant through-

\footnotetext{
This represents a $22^{\circ} \mathrm{C}\left(40^{\circ} \mathrm{F}\right)$ lower temperature difference than baseline temperature difference (baseline flue gas temperature $=288^{\circ} \mathrm{C}$, ambient temperature $=21^{\circ} \mathrm{C}$ ).
} 
out the forecast period (1980-2000). In the second case, we assumed step reductions in water heater energy use in 1980 of $11 \%$ for electric and $13 \%$ for gas units (item $2 \mathrm{~d}$ from Table 2). In the third case, we assumed greater reductions in 1980: $17 \%$ for electric and $27 \%$ for gas units (item 9 for electric and item 11 for gas units from Table 2). Model results, summarized in Table 10, show that both sets of design options save energy for the nation and save money for households. Reducing unit energy use by $11 \%$ for electric and $13 \%$ for gas saves a total of $3.1 \times 10^{18}$ joules between 1980 and 2000 . The present worth of the net economic benefits to households is $\$ 1.0$ billion (discounted to 1977 at a real interest rate of $10 \%$ ).

Table 10. Cumulative (1980-2000) effects of reducing water heater energy use $e^{a}$

\begin{tabular}{|c|c|c|}
\hline & Low & High \\
\hline \multicolumn{3}{|l|}{ Energy savings ( $10^{18}$ joules) } \\
\hline Electricity & 1.7 & 6.2 \\
\hline Gas & 1.2 & 1.0 \\
\hline $0 i 1$ & 0.2 & 0.4 \\
\hline Total & 3.1 & 7.6 \\
\hline \multicolumn{3}{|l|}{$\begin{array}{l}\text { Present worth of cost savings at } 10 \% \\
\text { real interest rate }\left(10^{9} 1975-\$\right)\end{array}$} \\
\hline $\begin{array}{l}\text { Fuels } \\
\text { Equipment }\end{array}$ & $\begin{array}{r}2.6 \\
-1.6\end{array}$ & $\begin{array}{r}6.6 \\
-2.7\end{array}$ \\
\hline Total & 1.0 & 3.9 \\
\hline
\end{tabular}

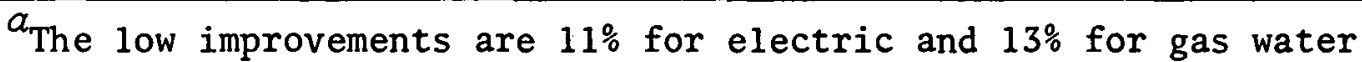
heaters. The high improvements are $17 \%$ for electric and $27 \%$ for gas water heaters; see Table 2. 
Reducing water heater energy use further (case 3) increases both the energy and economic benefits. The cumulative energy savings increase to $7.6 \times 10^{18}$ joules and the economic benefits increase to $\$ 3.9$ billion. The ratio of economic benefits (reduced fuel bills) to economic costs (higher equipment costs) for both sets of improvements is greater than 1.0 . For the $11 \% / 13 \%$ changes, the ratio is 1.6 ; for the $17 \% / 27 \%$ changes, the ratio is 2.4 . It appears likely that additional improvements in water heater performance would yield even larger energy and economic benefits than those discussed here.

These results show that improvements in water heater performance can yield large energy and economic benefits to the nation.

\section{CONCLUSIONS}

The model developed here provides a detailed picture of energy flows in residential gas and electric water heaters. The model is sufficiently flexible to handle different sizes, types (gas or electric), and operating environments (e.g., room temperature, water temperature, water usage rate). The model's estimates of energy use are in good agreement with those from related studies.

The primary purpose in developing this model is to evaluate the energy (and related cost) impacts of alternative water heater designs. A $5.6^{\circ} \mathrm{C}\left(10^{\circ} \mathrm{F}\right)$ reduction in thermostat setting is one of the most effective energy saving options, reducing fuel use $5 \%$ with no increase in purchase price. 
The largest heat loss in an electric water heater is conduction through jacket walls. Changing from fiberglass to urethane foam insulation reduces this heat loss and cuts energy use $11 \%$ while increasing purchase price $14 \%$. Energy use for a gas water heater can be reduced $13 \%$ with an increase in purchase price of $10 \%$. Payback periods for electric and gas water heaters are 1.0 and 2.3 years, respectively.

Adding insulation to the distribution line reduces heat loss during periods of no water withdrawal. Energy use for electric and gas water heaters can be cut $3 \%$. Payback periods are 2.4 and 10.0 years, respectively.

The main heat loss in gas water heaters is up the flue. Reduction of pilot rate by reducing the pilot orifice area is an effective design change; gas use is reduced $6 \%$ and purchase price remains unchanged.

The largest energy saving change to gas water heaters is elimination of the pilot light and addition of an electric ignitor and flue closure. This would eliminate flue losses during standby and reduce gas use $12 \%$. However, the large cost of parts and installation make this design change uneconomical at present gas prices.

Reducing excess air for combusion and increasing flue baffling in gas water heaters reduces gas use $2 \%$. The change in purchase price would be 1 ess than $1 \%$. The payback period is 0.6 year.

Total savings anticipated from all the options discussed for an electric water heater would be $17 \%$ and for a gas water heater (excluding addition of electric ignitor) $27 \%$. Retail prices would increase $27 \%$ and $26 \%$, respectively. Figures 1 and 2 and Table 2 show changes in retail price resulting from various design changes as a function of energy use. 


\section{ACKNOWLEDGEMENTS}

We thank Roger Carlsmith, Peter Cowling, Stephen Dole, Eugene Hise, Charles Howard, William S. Johnson, Esher Kweller, Melvin Meyerson, and William Walsh for their careful reviews of this report. We thank Ethel Cagle for typing this report. 


\section{REFERENCES}

1. E. Hirst et al., An Improved Engineering-Economic Model of Residential Energy Use, Oak Ridge National Laboratory, ORNL/CON-8, March 1977; also, E. Hirst, W. Lin, and J. Cope, An EngineeringEconomic Model of Residential Energy Use, Oak Ridge National Laboratory, ORNL/TM-5470, July 1976.

2. J. P. D'Acierno, R. J. Bertolami, and E. I. Chao, Energy Consumption in Residential Gas and Electric Water Heaters and Ranges, Oak Ridge National Laboratory, ORNL/MIT-226, February 25, 1976.

3. "1975 Statistical and Marketing Report," Merchandising Week, February 24, 1975 (and eariier annual statistical issues).

4. "Water Heaters: Gas and Electric," Consumer Reports, March 1976.

5. S. H. Dole, Energy Use and Conservation in the Residential Sector: A Regional Analysis, Rand Corporation R-1641-NSF, June 1975.

6. J. J. Mutch, Residential Water Heating: Fuel Conservation, Economics, and Public Policy, Rand Corporation, R-1498-NSF, May 1974.

7. R. A. Raynor, Appliance Efficiency Program--Water Heaters, Clothes Washers, Clothes Dryers, R. A. Ransom Company, Inc., July 15, 1976.

8. R. S. Quinn, The Effect of Increased Capital Expenditures as a Method of Reducing Electricity Demand for Hot Water Generation in a Home, Sc. M. Thesis, University of Tennessee, 1972.

9. W. D. Lee, Study of Energy-Saving Options for Refrigerators and Water Heaters, draft, Arthur D. Little, Inc., May 1976.

10. D. E. Spann and G. G. Slaughter, An Efficiency Evaluation and Consumer Economic Analysis of Domestic Water Heaters, Oak Ridge National Laboratory, forthcoming.

11. ASHRAE Handbook of Fundomentals, American Society of Heating Refrigerating and Air-Conditioning Engineers, Inc., 1972. 
APPENDIX B: Determination of flue loss

The American Gas Association developed a nomograph for determining flue loss as a function of percent excess air in flue gases and temperature difference between flue gases and ambient air (see Fig. B.1).9 This relationship is expressed empirically as:

$$
\mathrm{FL}=1.29 \mathrm{EA}^{0.147} \mathrm{~T}^{0.419}
$$

where

$\mathrm{T}=$ temperature difference between flue gases and ambient air, ${ }^{\circ} \mathrm{C}$. ORNL-DWG 77-5889
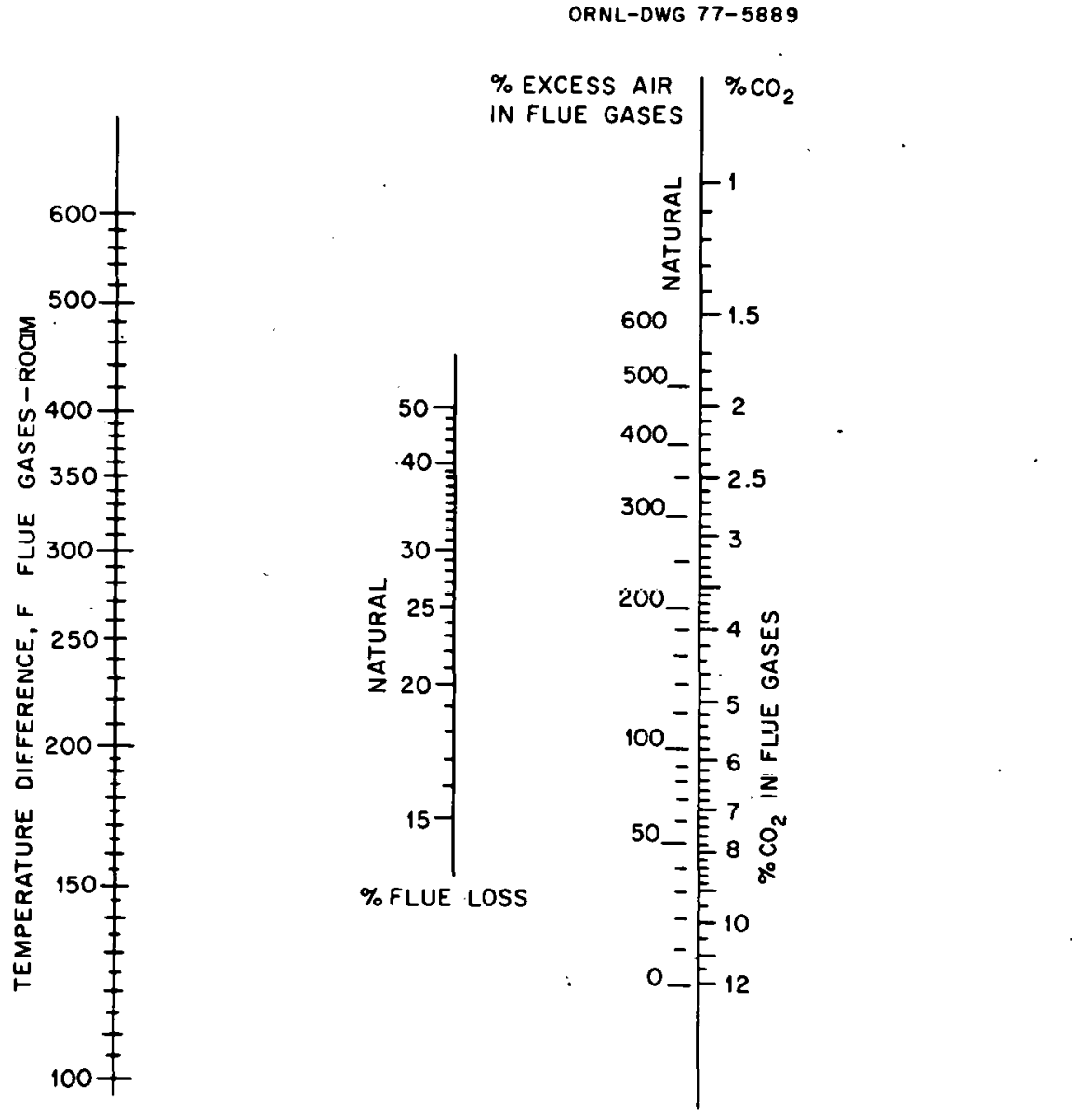

Fig. B.1. Flue loss as function of excess air and temperature. 
APPENDIX C: Sample calculations for a $0.19 \mathrm{~m}^{3}$ (50 gal) electric and a $0.15 \mathrm{~m}^{3}$ (40 gal) gas water heater

\section{Electric Water Heater}

Input values:

$$
\begin{aligned}
\mathrm{V} & =0.19 \mathrm{~m}^{3} \\
\dot{\mathrm{m}} & =0.27 \mathrm{~m}^{3} / \text { day } \\
\mathrm{C}_{\mathrm{p}} & =4.19 \times 10^{6} \mathrm{~J} / \mathrm{m}^{3}-{ }^{\circ} \mathrm{C} \\
\mathrm{T}_{\mathrm{W}} & =60^{\circ} \mathrm{C} \\
\mathrm{T}_{\text {wi }} & =12.8^{\circ} \mathrm{C} \\
\mathrm{T}_{\text {amb }} & =21.1^{\circ} \mathrm{C} \\
\mathrm{Q}^{\prime} & =3.68 \times 10^{6} \mathrm{~J} / \mathrm{m}-\mathrm{yr}-{ }^{\circ} \mathrm{C} \\
\mathrm{L} & =7.62 \mathrm{~m} \\
\mathrm{~A} & =2.81 \mathrm{~m} 2 \\
\Delta \mathrm{x} & =0.0508 \mathrm{~m} \\
\mathrm{k} & =161.0 \mathrm{~J} / \mathrm{m}-\mathrm{hr}-{ }^{\circ} \mathrm{C} \\
\mathrm{U} & =3513.3 \mathrm{~J} / \mathrm{m}^{2}-\mathrm{hr}-{ }^{\circ} \mathrm{C}
\end{aligned}
$$

1. Energy required to heat water:

$$
\begin{aligned}
E_{\text {water }} & =\dot{\mathrm{m}} \mathrm{c}_{\mathrm{p}}\left(\mathrm{T}_{\mathrm{w}}-\mathrm{T}_{w i}\right) 365 \\
& =\left(0.27 \mathrm{~m}^{3} / \text { day }\right)\left(4.19 \times 10^{6} \mathrm{~J} / \mathrm{m}^{3}{ }_{-}^{\circ} \mathrm{C}\right)(60-12.8)^{\circ} \mathrm{C} 365 \mathrm{days} / \mathrm{yr} \\
& =19.49 \times 10^{9} \mathrm{~J} / \mathrm{yr}
\end{aligned}
$$


2. Energy lost through jacket:

$$
\begin{aligned}
E_{\text {jacket }} & =U A\left(T_{w}-T_{\text {amb }}\right) 8760 \\
\text { loss } & =\left(3513.3 \mathrm{~J} / \mathrm{m}^{2}-\mathrm{hr}-{ }^{\circ} \mathrm{C}\right)\left(2.81 \mathrm{~m}^{2}\right)(60-21.1)^{\circ} \mathrm{C}(8760 \mathrm{hr} / \mathrm{yr}) \\
& =3.36 \times 10^{9} \mathrm{~J} / \mathrm{yr}
\end{aligned}
$$

3. Energy lost through distribution pipe:

$$
\begin{aligned}
E_{\text {pipe }} & =Q^{\prime} \mathrm{L}\left(\mathrm{T}_{\mathrm{w}}-\mathrm{T}_{\mathrm{amb}}\right) \\
\text { loss } & =\left(3.68 \times 10^{6} \mathrm{~J} / \mathrm{m}-\mathrm{yr}-{ }^{\circ} \mathrm{C}\right)(7.62 \mathrm{~m})(60-21.1)^{\circ} \mathrm{C} \\
& =1.09 \times 10^{9} \mathrm{~J} / \mathrm{yr}
\end{aligned}
$$

4. Total energy input:

$$
\begin{aligned}
E_{\text {in }} & =E_{\text {water }}+\underset{\text { loss }}{E_{\text {jacket }}}+E_{\text {pipe }} \\
& =(19.49+3.36+1.09) \times 10^{9} \mathrm{~J} / \mathrm{yr} \\
& =23.9 \times 10^{9} \mathrm{~J} / \mathrm{yr}
\end{aligned}
$$

5. Efficiency:

$$
\begin{aligned}
\eta & =E_{\text {water }} / E_{\text {in }} \times 100 \\
& =\left(19.49 \times 10^{9} / 23.9 \times 10^{9}\right) \times 100=81 \%
\end{aligned}
$$




\section{Gas Water Heater}

Input values:

$$
\begin{aligned}
\mathrm{V} & =0.15 \mathrm{~m}^{3} \\
\mathrm{~A} & =1.623 \mathrm{~m}^{2} \\
\Delta \mathrm{x} & =0.0254 \mathrm{~m} \\
\mathrm{U} & =7882.5 \mathrm{~J} / \mathrm{m}^{2}-\mathrm{hr}-{ }^{\circ} \mathrm{C} \\
n_{\mathrm{b}} & =75 \% \\
n_{\mathrm{p}} & =22 \%
\end{aligned}
$$

$\dot{\mathrm{m}}, \mathrm{c}_{\mathrm{p}}, \mathrm{T}_{\mathrm{w}}, \mathrm{T}_{\mathrm{wi}}, \mathrm{T}_{\text {amb }}, \mathrm{Q}^{\prime}, \mathrm{L}$, and $\mathrm{k}$ are same as for electric water heater.

1. From electric water heater calculations (above):

$$
\begin{aligned}
& E_{\text {water }}=19.49 \times 10^{9} \mathrm{~J} / \mathrm{yr} \\
& E_{\text {pipe }}=1.09 \times 10^{9} \mathrm{~J} / \mathrm{yr} \\
& \text { loss }
\end{aligned}
$$

2. Energy lost through jacket:

$$
\begin{aligned}
\underbrace{}_{\text {jacket }} & =U A\left(T_{w}-T_{\text {amb }}\right) 8760 \\
\text { loss } & =\left(7882.5 \mathrm{~J} / \mathrm{m}^{2}-\mathrm{hr}-{ }^{\circ} \mathrm{C}\right)\left(1.623 \mathrm{~m}^{2}\right)(60-21.1)^{\circ} \mathrm{C}(8760 \mathrm{hr} / \mathrm{yr}) \\
& =4.36 \times 10^{9} \mathrm{~J} / \mathrm{yr}
\end{aligned}
$$


3. Remaining energy terms are functions of main burner on-time, $t$ :

$$
\begin{aligned}
& E_{\text {in }}= E_{\text {water }}+E_{\substack{\text { jacket } \\
\text { loss }}}+\underset{\substack{\text { pipe } \\
\text { loss }}}{E_{\text {loss }}}+E_{\text {burner }}+E_{\text {pilot }} \text { loss } \\
&\left(2.787 \times 10^{8}\right)(0.15) t+6.9 \times 10^{9}=(19.49+4.36+1.09) \times 10^{9} \\
&+\left(2.787 \times 10^{8}\right)(0.15) t(1-0.75) \\
&+\left(7.9 \times 10^{5}\right)[(1-0.75) t+(1-0.22)(8760-t)] \\
& t=737 \mathrm{hr} / \mathrm{yr}
\end{aligned}
$$

4. Energy lost up flue:

$$
\begin{aligned}
& \mathrm{E}_{\text {burner }}=\left(2.787 \times 10^{8}\right) \mathrm{Vt}\left(1-\eta_{\mathrm{b}}\right) \\
& \text { loss }=\left(2.787 \times 10^{8} \mathrm{~J} / \mathrm{hr}-\mathrm{m}^{3}\right)\left(0.15 \mathrm{~m}^{3}\right)(737 \mathrm{hr} / \mathrm{yr})(1-0.75) \\
& =7.70 \times 10^{9} \mathrm{~J} / \mathrm{yr} \\
& E_{\text {pilot }}=\left(7.913 \times 10^{5}\right)\left(1-i_{b}\right) t+\left(1={ }_{p}\right)(8700-\mathrm{l}) \\
& \text { loss }=\left(7.913 \times 10^{5} \mathrm{~J} / \mathrm{hr}\right)[(1-0.75)(737 \mathrm{hr} / \mathrm{yr}) \\
& +(1-0.22)(8760-737) \mathrm{hr} / \mathrm{yr}] \\
& =5.10 \times 10^{9} \mathrm{~J} / \mathrm{yr} \text {. }
\end{aligned}
$$

5. Total energy input:

$$
\begin{aligned}
E_{\text {in }} & =\left(2.787 \times 10^{8}\right) \mathrm{Vt}+6.9 \times 10^{9} \\
& =\left(2.787 \times 10^{8} \mathrm{~J} / \mathrm{hr}-\mathrm{m}^{3}\right)\left(0.15 \mathrm{~m}^{3}\right)(737 \mathrm{hr} / \mathrm{yr})+6.9 \times 10^{9} \mathrm{~J} / \mathrm{yr} \\
& =37.7 \times 10^{9} \mathrm{~J} / \mathrm{yr}
\end{aligned}
$$


6. Efficiency:

$$
\begin{aligned}
\eta & =E_{\text {water }} / E_{\text {in }} \times 100 \\
& =\left(19.49 \times 10^{9} \mathrm{~J} / \mathrm{yr} / 37.7 \times 10^{9} \mathrm{~J} / \mathrm{yr}\right) \times 100=52 \%
\end{aligned}
$$

ENERGY CONSUMPTION OF A 0.19 CU M ELECTRIC WATER HEATER

TANK WATER

60.0
INLET WATER

12.8
AMB IENT

21.1

LENGTH OF DISTRIBUTION PIPE $=7.62 \mathrm{M}$

THICKNESS OF FIBERGLASS INSULATION AROUND DISTRIBUTION LINE $=0.0000 \mathrm{M}$ SURFACE AREA $=2.81 \mathrm{SQ} M$

JACKET INSULATION THICKNESS $=0.0508 \mathrm{M}$

JACKET INSULATION THERMAL CONDUCTIVITY $=161.0 \mathrm{~J} / \mathrm{M}-\mathrm{HR}-\mathrm{C}$

\section{TABLE C. 1}

ENERGY

JOULE/YEAR

(BILLION)

TO HEAT WATER

LOST THROUGH JACKET WALLS

LOST THROUGH DISTRIBUTION PIPE

19.490

3.366

1.091

TOTAL INPUT

23.947

WATER HEATER EFFICIENCY $=81.4 \%$

OPERATING COST $=\$ 213.13 /$ YEAR 
ENERGY CONSUMPTION OF A 0.15 CU M GAS WATER HEATER

TANK WATER

TEMPERATURE

60.0

INLET WATER

AMBIENT

12.8

21.1

LENGTH OF DISTRIBUTION PIPE $=7.62 \mathrm{M}$

THICKNESS OF FIBERGLASS INSULATION AROUND DISTRIBUTION LINE $=0.0000 \mathrm{M}$ SURFACE AREA $=1.62$ SQ M

JACKET INSULATION THICKNESS $=0.0254 \mathrm{M}$

JACKET INSULATION THERMAL CONDUCTIVITY $=161.0 \mathrm{~J} / \mathrm{M}-H R-C$

MAIN BURNER RATE $=278700000.0 \mathrm{~J} / \mathrm{HR}-\mathrm{CU} \mathrm{M}$

PILOT RATE $=791300.0 \mathrm{~J} / \mathrm{HR}$

MAIN BURNER EFFICIENCY $=75.0 \%$

PILOT EFFICIENCY (DURING STANDBY) $=22.0 \%$

BURNER ON-T.IME $=737.0$ HOURS $/$ YEAR

TABLE C. 2

ENERGY

TO HEAT WATER

LOST TIIROUGII JACKET WALLS

LOST THROUGH DISTRIBUTION PIPE

FLUE LOSS

A) MAIN BURNER

B) PILOT

TOTAL INPUT

WATER HEATER EFFICIENCY $=51.6 \%$

OPERATING COST $=\$ 60.38 /$ YEAR
JOULE/YEAR

(BILLION)

19.490

4.360

1.091

7.702

5.098

37.740 
APPENDIX D: Energy-conserving options

ELECTRIC WATER HEATER:

ENERGY SAVING OPTION

* INCREASE JACKET INSULATION THICKNESS

ENERGY SAVINGS $=0.929$ (BILLION) JOULES/YEAR

JACKET INSULATION THICKNESS $=0.0762 \mathrm{M}$

JACKET INSULATION THERMAL CONDUCTIVITY $=161.0 \mathrm{~J} / \mathrm{M}-\mathrm{HR}-\mathrm{C}$

TABLE D. 1

ENERGY

TO HEAT WATER

LOST THROUGH JACKET WALLS

LOST THROUGH DISTRIBUTION PIPE

TOTAL INPUT

WATER HEATER EFFICIENCY $=84.7 \%$
JOULE/YEAR

(BILLION)

19.490

2.438

1.091

23.018

ENERGY SAVING OPTION

* INCREASE JACKET INSULATION THICKNESS

ENERGY SAVINGS $=1.360($ BILLION $)$ JOULES/YEAR

JACKET INSULATION THICKNESS - $0.1016 \mathrm{M}$

JACKET INSULATION THERMAL CONDUCTIVITY $=161.0 \mathrm{~J} / \mathrm{M}-\mathrm{HR}-\mathrm{C}$

TABLE D.2

ENERGY

JOULE/YEAR

(BILLION)

TO HEAT WATER

19.490

LOST THROUGH JACKET WALLS

2.006

LOST THROUGH DISTRIBUTION PIPE

1.091

TOTAL INPUT

22.587

WATER HEATER EFFICIENCY $=86.3 \%$ 
ENERGY SAVING OPTION

* INCREASE JACKET INSULATION THICKNESS

ENERGY SAVINGS $=1.604($ BILLION) JOULES/YEAR

JACKET INSULATION THICKNESS $=0.1270 \mathrm{M}$

JACKET INSULATION THERMAL CONDUCTIVITY $=161.0 \mathrm{~J} / \mathrm{M}-\mathrm{HR}-\mathrm{C}$

\section{TABLE D.3}

ENERGY

JOULE/YEAR

(BILLION)

TO HEAT WATER

19.490

LOST THROUGH JACKET WALLS

1.762

LOST THROUGH DISTRIBUTION PIPE

1.091

TOTAL INPUT

22.343

WATER HEATER EFFICIENCY $=87.2 \%$

ENERGY SAVING OPTION

* REDUCE JACKET INSULATION THERMAL CONDUCTIVITY

ENERGY SAVINGS $=1.987$ (BILLION) JOULES/YEAR

JACKET INSULATION THICKNESS $=0.0508 \mathrm{M}$

JACKET INSULATION THERMAL CONDUCTIVITY $=70.0 \mathrm{~J} / \mathrm{M}-\mathrm{HR}-\mathrm{C}$

TABLE D.4

ENERGY

JOULE/YEAR

(BILLION)

TO HEAT WATER

19.490

LOST THROUGH JACKET WALLS

1.379

LOST THROUGH DISTRIBUTION PIPE

1.091

TOTAL · INPUT

21.960

WATER HEATER EFFICIENCY $=88.8 \%$ 


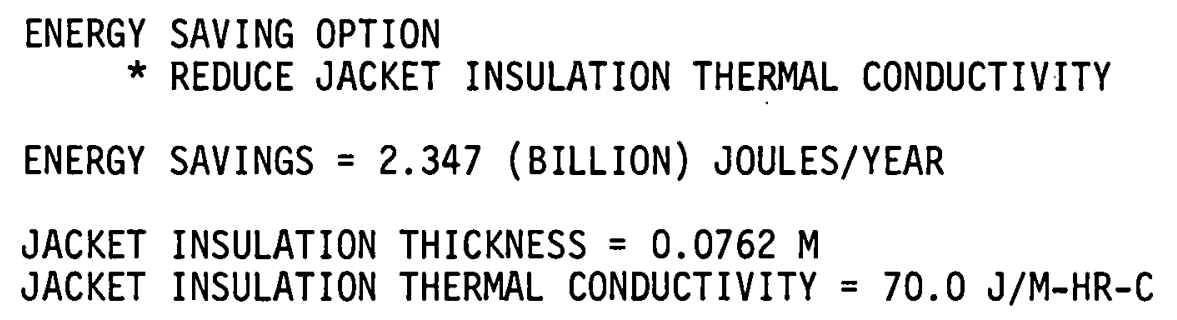

TABLE D.5

\section{ENERGY}

TO HEAT WATER

LOST THROUGH JACKET WALLS

LOST THROUGH DISTRIBUTION PIPE

TOTAL INPUT

WATER HEATER EFFICIENCY $=90.2 \%$
JOULE/ YEAR

(BILLION)

$$
\begin{array}{r}
19.490 \\
1.020 \\
1.091 \\
21.600
\end{array}
$$

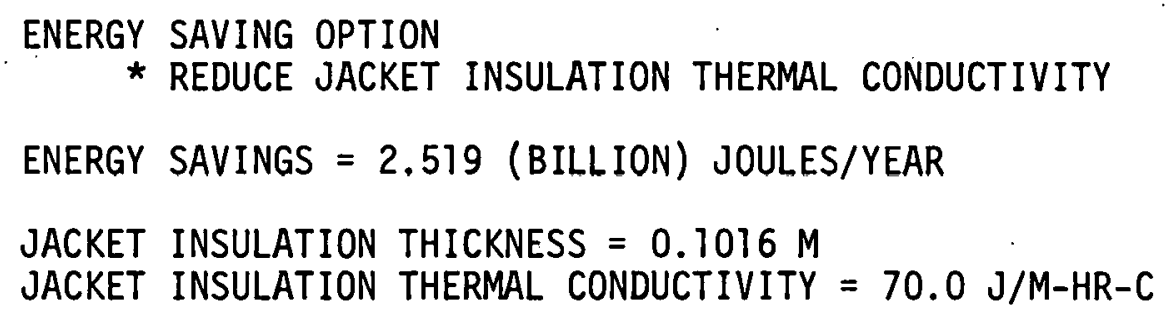

TABLE D. 6

ENERGY JOULE/YEAR (BILLION)

TO HEAT. WATER LOST THROUGH JACKET WALLS 


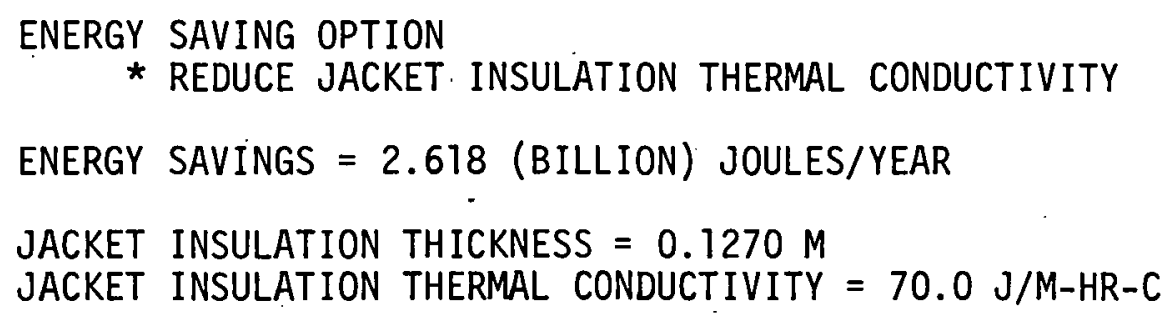

TABLE D.7

$\begin{array}{lr}\text { ENERGY } & \begin{array}{r}\text { JOULE/YEAR } \\ \text { (BILLION) }\end{array} \\ \text { TO HEAT WATER } & 19.490 \\ \text { LOST THROUGH JACKET WALLS } & 0.749 \\ \text { LOST THROUGH DISTRIBUTION PIPE } & 1.091 \\ \text { TOTAL INPUT } & 21.330 \\ & \\ \text { WATER HEATER EFFICIENCY }=91.4 \% & \end{array}$

ENERGY SAVING OPTION
* REDUCE THERMOSTAT SETTING

ENERGY SAVINGS $=1.220$ (BILLION) JOULES/YEAR

$\begin{array}{lll}\text { TANK WATER } & \text { INLET WATER }\end{array}$

$\begin{array}{llll}\text { TEMPERATURE } & 54.4 & 12.8 & 21.1\end{array}$

TABLE D. 8
ENERRYY
JOULE/YEAR
(BILLION)
TO HEAT WATER
LOST THROUGH JACKET WALLS
18.912
LOST THROUGH DISTRIBUTION PIPE
2.882
0.934
TOTAL INPUT
22.727
WATER HEATER EFFICIENCY $=83.2 \%$ 
ENERGY SAVING OPTION

* ADD FIBERGLASS INSULATION TO DISTRIBUTION PIPE

ENERGY SAVINGS $=0.631$ (BILLION) JOULES/YEAR

LENGTH OF DISTRIBUTION PIPE $=7.62 \mathrm{M}$

THICKNESS OF FIBERGLASS INSULATION AROUND DISTRIBUTION LINE $=0.0127 \mathrm{M}$

TABLE D.9

ENERGY

TO HEAT WATER

LOST THROUGH JACKET WALLS

LOST THROUGH DISTRIBUTION PIPE

TOTAL INPUT

WATER HEATER EFFICIENCY $=83.6 \%$
JOULE/YEAR

(BILLION)

19.490

3.366

0.458

23.316

ENERGY SAVING OPTION

* ADD FIBERGLASS INSULATION TO DISTRIBUTION PIPE

ENERGY SAVINGS $=0.747$ (BILLION) JOULES/YEAR

LENGTH OF DISTRIBUTION PIPE $=7.62 \mathrm{M}$

THICKNESS OF FIBERGLASS INSULATION AROUND DISTRIBUTION LINE $=0.0254 \mathrm{M}$

TABLE D. 10

ENERGY

JOULE/YEAR

(BILLION)

TO HEAT WATER

19.490

LOST THROUGH JACKET WALLS

LOST THROUGH DISTRIBUTION PIPE

3.366

0.344

TOTAL INPUT

23.200

WATER HEATER EFFICIENCY $=84.0 \%$ 
GAS WATER HEATER:

ENERGY SAVING OPTION

*INCREASE JACKET INSULATIION THICKNESS

ENERGY SAVINGS $=2.799$ (BILLION) JOULES/YEAR

JACKET INSULATION THICKNESS $=0.0508 \mathrm{M}$

JACKET INSULATION THERMAL CONDUCTIVITY $=161.0 \mathrm{~J} / \mathrm{M}-\mathrm{HR}-\mathrm{C}$

BURNER ON-TIME $=670.0 \mathrm{HOURS} / \mathrm{YEAR}$

TABLE D. 11

ENERGY

JOULE/YEAR

(BILLION)

TO HEAT WATER

LOST THROUGH JACKET WALL

19.490

LOST THROUGH DISTRIBUTION PIPE

2.232

FLUE LOSS

A) MAIN BURNER

B) PILOT

1.091

7.002

5.126

TOTAL INPUT

34.941

WATER HEATER EFFICIENCY $=55.8 \%$

ENERGY SAVING OPTION

* INCREASE JACKET INSULATION TIIICKNESS

ENERGY SAVINGS $=3.590$ (BILLION) JOULES/YEAR

JACKET INSULATION THICKNESS $=0.0762 \mathrm{M}$

JACKET INSULATION THERMAL CONDUCTIVITY $=161.0 \mathrm{~J} / \mathrm{M}-H R-C$

BURNER ON-TIME $=651.1$ HOURS $/$ YEAR

TABLE D. 12

ENERGY

JOULE/YEAR

(BILLION)

TO HEAT WATER

LOST THROUGH JACKET WALLS

LOST THROUGH DISTRIBUTION PIPE

FLUE LOSS

A) MAIN BURNER

B) PILOT

19.490

1.631

1.091

6.805

5.134

TOTAL INPUT

34.151

WATER HEATER EFFICIENCY $=57.1 \%$ 


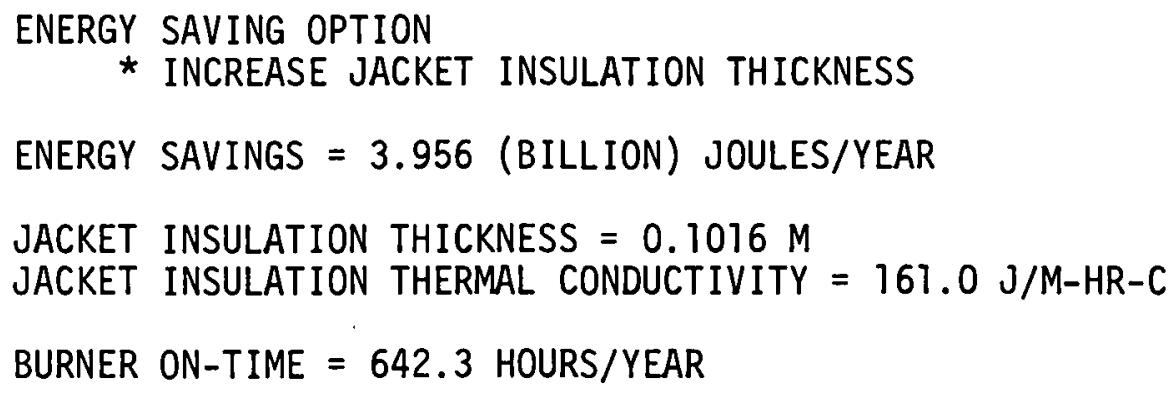

TABLE D. 13

ENERGY

TO HEAT WATER

LOST THROUGH JACKET WALLS

19.490

LOST THROUGH DISTRIBUTION PIPE

1.353

FLUE. LOSS

A) MAIN BURNER

1.091

6.713

B) PILOT

5.137

TOTAL INPUT

33.785

WATER HEATER EFFICIENCY $=57.7 \%$

\author{
ENERGY SAVING OPTION \\ * INCREASE JACKET INSULATION THICKNESS \\ ENERGY SAVINGS $=4.162($ BILLION $)$ JOULES/YEAR \\ JACKET INSULATION THICKNESS $=0.1270 \mathrm{M}$ \\ JACKET INSULATION THERMAI. CONDUCTIVITY $=161.0 \mathrm{~J} / \mathrm{M}-\mathrm{HR}-\mathrm{C}$ \\ BURNER ON-TIME $=637.4$ HOURS $/$ YEAR
}

TABLE D. 14

ENERGY

JOULE/YEAR

(BILLION)

TO HEAT WATER

19.490

LOST THROUGH JACKET WALLS

1.197

LOST THROUGH DISTRIBUTION PIPE

1.091

FLUE LOSS

A) MAIN BURNER

6.662

B) PILOT

5.139

TOTAL INPUT

33.578

WATER HEATER EFFICIENCY $=58.0 \%$ 


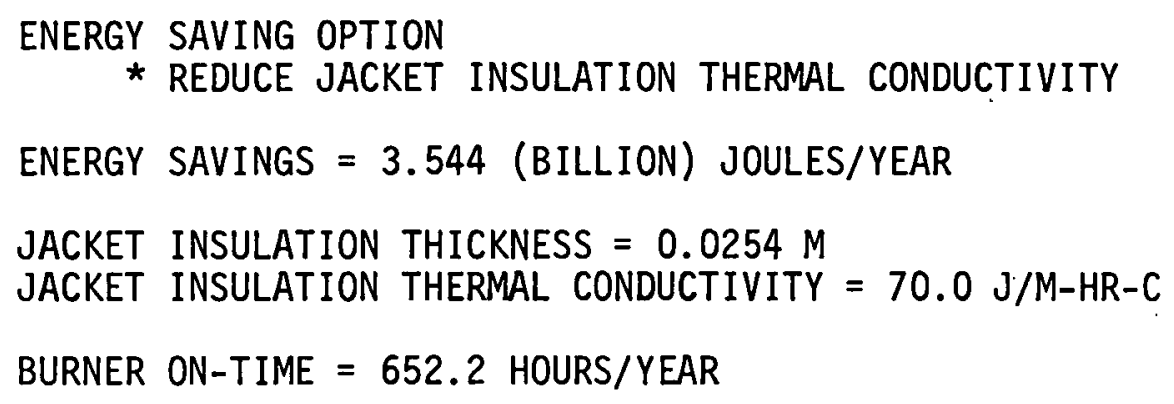

B) PILOT

TOTAL INPUT

WATER HEATER EFFICIENCY $=57.0 \%$

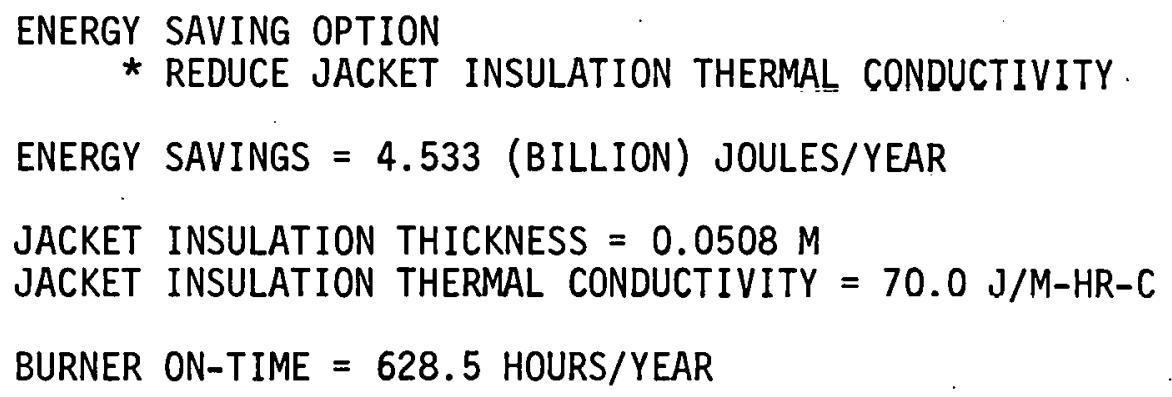

TABLE D.16

ENERGY

TO HEAT WATER

LOST THROUGH JACKET WALLS

19.490

LOST THROUGH DISTRIBUTION PIPE

FLUE LOSS

A) MAIN BURNER

B) PILOT

0.914

1.091

6.569

5,143

TOTAL INPUT

33.207

WATER HEATER EFFICIENCY $=58.7 \%$ 
ENERGY SAVING OPTION

* REDUCE JACKET INSULATION THERMAL CONDUCTIVITY

ENERGY SAVINGS $=4.839$ (BILLION) JOULES/YEAR

JACKET INSULATION THICKNESS $=0.0762 \mathrm{M}$

JACKET INSULATION THERMAL CONDUCTIVITY $=70.0 \mathrm{~J} / \mathrm{M}-H R-C$

BURNER ON-TIME $=621.2 \mathrm{HOURS} /$ YEAR

TABLE D. 17

ENERGY

JOULE/YEAR

(BILLION)

TO HEAT WATER

LOST THROUGH JACKET WALLS

19.490

LOST THROUGH DISTRIBUTION PIPE

0.682

FLUE LOSS

A) MAIN BURNER

1.091

B) PILOT

6.492

5.146

TOTAL INPUT

32.902

WATER HEATER EFFICIENCY $=59.2 \%$

ENERGY SAVING OPTION

* REDUCE JACKET INSULATION THERMAL CONDUCTIVITY

ENERGY SAVINGS $=4.984(B I L L I O N)$ JOULES/YEAR

JACKET INSULATION THICKNESS $=0.1016 \mathrm{M}$

JACKET INSULATION THERMAL CONDUCTIVITY $=70.0 \mathrm{~J} / \mathrm{M}-\mathrm{HR}-\mathrm{C}$

BURNER ON-TIME $=617.7$ HOURS/YEAR

TABLE D. 18

ENERGY

JOULE/YEAR

(BILLION)

TO HEAT WATER

19.490

LOST THROUGII JACKET WALLS

0.572

LOST THROUGH DISTRIBUTION PIPE

1.091

FLUE LOSS

A) MAIN BURNER

6.456

B) PILOT

5.148

TOTAL INPUT

32.756

WATER HEATER EFFICIENCY $=59.5 \%$ 
ENERGY SAVING OPTION

*REDUCE JACKET INSULATION THERMAL CONDUCTIVITY

ENERGY SAVINGS $=5.067$ (BILLION) JOULES/YEAR

JACKET INSULATION THICKNESS $=0.1270 \mathrm{M}$

JACKET INSULATION THERMAL CONDUCTIVITY $=70.0 \mathrm{~J} / \mathrm{M}-\mathrm{HR}-\mathrm{C}$

BURNER ON-TIME $=615.7$ HOURS $/$ YEAR

TABLE D.19

ENERGY

JOULE/YEAR

(BILLION)

TO HEAT WATER

19.490

LOST THROUGH JACKET WALLS

0.509

LOST THROUGH DISTRIBUTION PIPE

1.091

FLUE LOSS

A) MAIN BURNER

B) PILOT

6.435

5.149

TOTAL . INPUT

32.673

WATER HEATER EFFICIENCY $=59.7 \%$

ENERGY SAVING OPTION

* REDUCE THERMOSTAT SETTING

ENERGY SAVINGS $=1.793$ (BILLION) JOULES/YEAR

TANK WATER

54.4

TEMPERATURE

BURNER ON-TIME $=694.1$ HOURS $/$ YEAR

TABLE D. 20

ENERGY

INLET:WATER

AMBIENT

12.8

21.1

\author{
ENERGY
}

TO HEAT WATER

LOST THROUGH JACKET WALLS

LOST TRHOUGH DISTRIBUTION PIPE

FLUE LOSS - A) MAIN BURNER

B) PILOT

JOULE/YEAR

(BILLION)

TOTAL INPUT

18.912

3.732

0.934

7.254

5.116

35.947

WATER HEATER EFFICIENCY $=52.6 \%$ 
ENERGY SAVING OPTION

* ADD FIBERGLASS INSULATION TO DISTRIBUTION PIPE

ENERGY SAVINGS $=0.831$ (BILLION) JOULES/YEAR

LENGTH OF DISTRIBUTION PIPE $=7.62 \mathrm{M}$

THICKNESS OF FIBERGLASS INSULATION AROUND DISTRIBUTION LINE $=0.0127 \mathrm{M}$ BURNER ON-TIME $=717.1$ HOURS/YEAR

TABLE D.21

ENERGY

TO HEAT WATER

LOST THROUGH JACKET WALLS

LOST THROUGH DISTRIBUTION PIPE

FLUE LOSS

A) MAIN BURNER

B) PILOT

TOTAL INPUT
JOULE/YEAR

(BILLION)

19.490

4.360

0.459

7.494

5.106

36.910

WATER HEATER EFFICIENCY $=52.8 \%$

ENERGY SAVING OPTION

* ADD FIBERGLASS INSULATION TO DISTRIBUTION PIPE

ENERGY SAVINGS $=0.983$ (BILLION) JOULES/YEAR

LENGTH OF DISTRIBUTION PIPE $=7.62 \mathrm{M}$

THICKNESS OF FIBERGLASS INSULATION AROUND DISTRIBUTION LINE $=0.0254 \mathrm{M}$

BURNER UN-TIME $=713.4$ HOURS/YEAR

TABLE 0.22

ENERGY

JOULE/YEAR

(BILLION)

TO HEAT WATER

LOST THROUGH JACKET WALLS

19.490

LOST THROUGH DISTRIBUTION PIPE

FLUE LOSS

A) MAIN BURNER

B) PILOT

4.360

0.344

7.456

5.108

TOTAL INPUT

36.758

WATTER HEATER EFFICIENCY $=53.0 \%$ 


\author{
ENERGY SAVING OPTION \\ * REDUCE PILOT RATE \\ ENERGY SAVINGS $=2.102$ (BILLION) JOULES/YEAR \\ PILOT RATE $=422024.0 \mathrm{~J} / \mathrm{HR}$ \\ BURNER ON-TIME $=764.1$ HOURS/YEAR
}

TABLE D.23

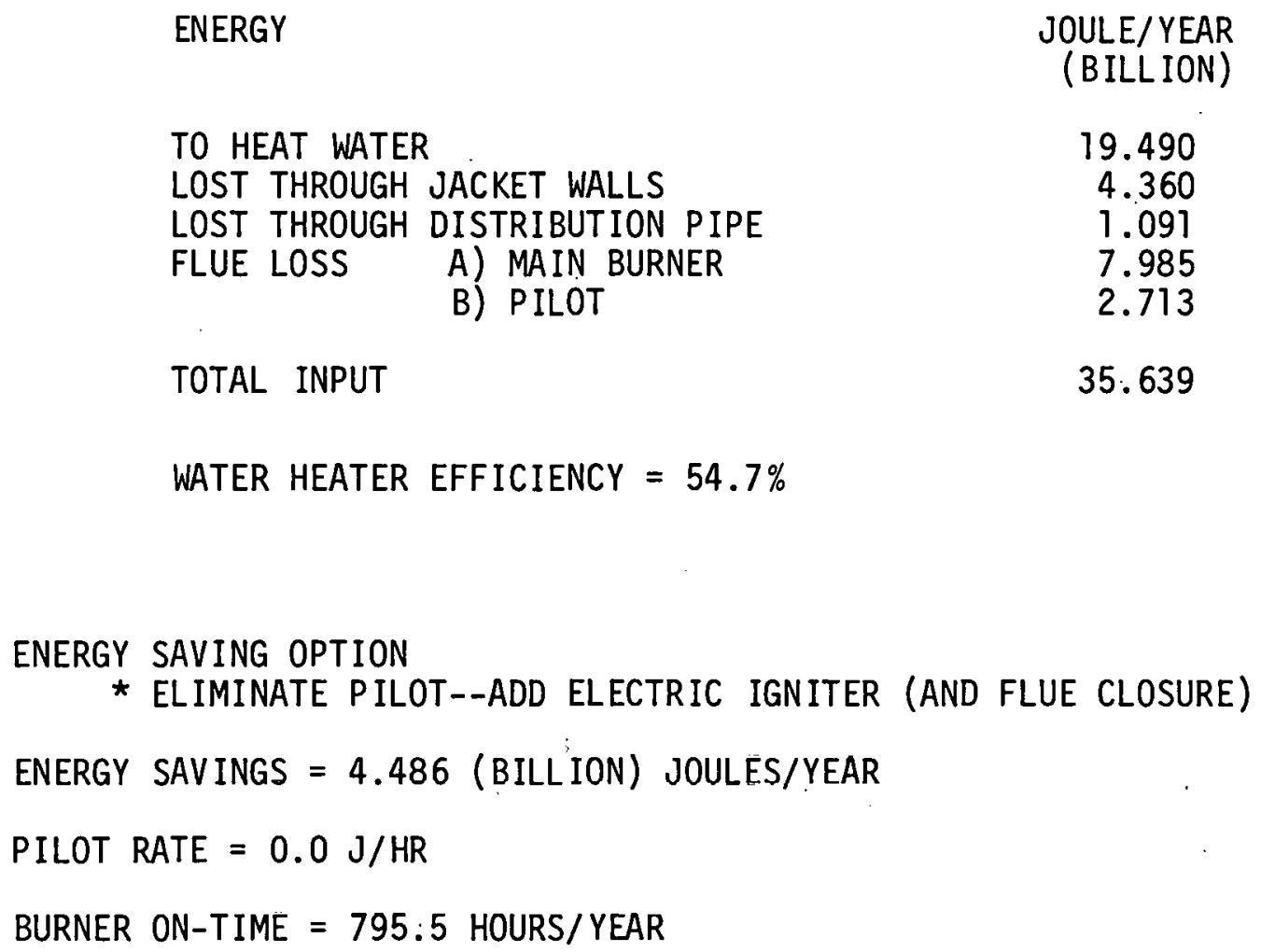

TOTAL INPUT

WATER HEATER EFFICIENCY $=54.7 \%$

TABLE D.24

ENERGY

TO HEAT WATER

LOST THROUGH JACKET WALLS

19.490

LOST THROUGH DISTRIBUTION PIPE

FLUE LOSS

A) MAIN BURNER

B) PILOT

4.360

1.091

8:313

0.000

TOTAL INPUT

WATER HEATER EFFICIENCY $=58.6 \%$ 
ENERGY SAVING OPTION

* REDUCE EXCESS AIR FOR COMBUSTION (INCREASE FLUE BAFFLING)

ENERGY. SAVINGS $=1.116($ BILLION) JOULES/YEAR

EXCESS AIR $=40 \%$

TEMPERATURE DIFFERENCE $=244^{\circ} \mathrm{C}$

BURNER ON-TIME $=710.3 \mathrm{HOURS} / \mathrm{YEAR}$

TABLE D. 25

ENERGY

JOULE/YEAR

(BILLION)

TO HEAT WATER

19.490

LOST THROUGH JACKET WALLS

4.360

LOST THROUGH DISTRIBUTION PIPE

1.091

FLUE LOSS

A) MAIN BURNER

B) PILOT

6.591

5.093

TOTAL INPUT

36.624

WATER HEATER EFFICIENCY $=53.2 \%$ 
THIS PAGE

\section{WAS INTENTIONALLY \\ LEFT BLANK}


ORNL/CON-10

\section{INTERNAL DISTRIBUTION}

1. S. I. Auerbach

2. S. E. Beall

3. D. J. Bjornstad

4. D. Brooks

5. J. R. Buchanan

6. R. S. Carlsmith

7. J. Carney

8. W. S. Chern

9. T. J. Clifford

10. S. Cohn

11. J. Cope

12. C. G. Crafton

13. F. L. Culler

14. R. M. Davis

15. J. G. Delene

16. W. Fulkerson

17. G. S. Gill

18. W. R. Griffith

19. M. Guthrie

20. N. Hardin

21. V. 0. Haynes

22. N. E. Hinkle

23. E. A. Hirst

24. J. R. Jackson

25. P. L. Johnson

26. S. I. Kaplan

27. D. Kaserman
28. R. S. Livingston

29. H. M. Long

30. J. W. Michel

31. R. E. Minturn

32. W. R. Mixon

33. J. C. Moyers

34. E. A. Nephew

35. H. Postma

36. M. W. Rosenthal

37. T. H. Row

38. R. L. Spore

39. E. G. Struxness

40. D. B. Trauger

41. G. U. Ulrikson

42. D. J. Walukas

43. A. M. Weinberg

44. H. E. Zittel

45. A. Zucker

46. Biology Division Library

47-48. Central Research Library

49. Institute of Energy Analysis, ORAU

50. Laboratory Records, ORNL R.C.

51-52. Laboratory Records Dept.

53. ORNL Patent Office

54. Document Reference Section

\section{EXTERNAL DISTRIBUTION}

55. Research and Technical Support Division, ERDA-ORO

56-82. Technical Information Center, ERDA, P. 0. Box 62, Oak Ridge, Tennessee 37830

83-600. External Energy Conservation Distribution Mailing List and Energy Conservation Office. 